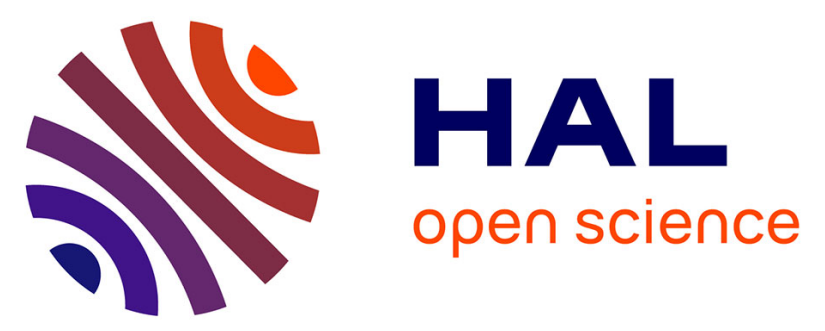

\title{
231Pa and 230Th in the Arctic Ocean: Implications for boundary scavenging and 231Pa230Th fractionation in the Eurasian Basin
}

Sandra Gdaniec, Matthieu Roy-Barman, Martin Levier, Ole Valk, Michiel

Rutgers van Der Loeff, Lorna Foliot, Arnaud Dapoigny, Lise Missiaen, Carl-Magnus Mörth, Per Andersson

\section{To cite this version:}

Sandra Gdaniec, Matthieu Roy-Barman, Martin Levier, Ole Valk, Michiel Rutgers van Der Loeff, et al.. 231Pa and 230Th in the Arctic Ocean: Implications for boundary scavenging and 231Pa230Th fractionation in the Eurasian Basin. Chemical Geology, 2020, 532, pp.119380. 10.1016/j.chemgeo.2019.119380 . hal-02467573

\section{HAL Id: hal-02467573 \\ https://hal.science/hal-02467573}

Submitted on 21 Dec 2021

HAL is a multi-disciplinary open access archive for the deposit and dissemination of scientific research documents, whether they are published or not. The documents may come from teaching and research institutions in France or abroad, or from public or private research centers.
L'archive ouverte pluridisciplinaire HAL, est destinée au dépôt et à la diffusion de documents scientifiques de niveau recherche, publiés ou non, émanant des établissements d'enseignement et de recherche français ou étrangers, des laboratoires publics ou privés.

\section{(ㅇ)(1) $\$$}

Distributed under a Creative Commons Attribution - NonCommerciall 4.0 International 


\title{
${ }^{231} \mathrm{~Pa}$ and ${ }^{230} \mathrm{Th}$ in the Arctic Ocean: implications for Boundary Scavenging and ${ }^{231} \mathrm{~Pa}^{230} \mathrm{Th}$ fractionation in the Eurasian Basin
}

\author{
Sandra Gdaniec a,b,c, Matthieu Roy-Barman ${ }^{c}$, Martin Levier ${ }^{c}$, Ole Valk ${ }^{d}$, Michiel Rutgers van \\ der Loeff $^{\mathrm{d}}$, Lorna Foliot ${ }^{c}$, Arnaud Dapoignyc ${ }^{\mathrm{c}}$, Lise Missiaen ${ }^{\mathrm{c},}$, Carl-Magnus Mörth ${ }^{\mathrm{a}}$, Per S. \\ Andersson ${ }^{b}$ \\ a Stockholm University, Department of Geological Sciences, Stockholm, Sweden \\ b Swedish Museum of Natural History, Department of Geosciences, Stockholm, Sweden \\ c Laboratoire des Sciences du Climat et de l'Environnement, LSCE/IPSL, CEA-CNRS-UVSQ \\ Université Paris-Saclay, Gif-sur-Yvette, France \\ d Alfred Wegener Institute, Helmholtz Centre for Polar and Marine Research, Bremerhaven, Germany \\ *Present address: Climate Change Research Centre, University of New South Wales, Sydney, \\ Australia
}

Corresponding Author:

Sandra Gdaniec

Sandra.gdaniec@nrm.se

Frescativägen 40

11418 Stockholm, Sweden

Email addresses: sandra.gdaniec@nrm.se (S.Gdaniec), matthieu.roy-barman@lsce.ipsl.fr (M. Roy-Barman), ole.valk@awi.de (O. Valk), mloeff@awi.de (M. Rutgers van der Loeff),martin.levier@Isce.ipsl.fr (M. Levier), lorna.foliot@Isce.ipsl.fr (L.Foliot), arnaud.dapoigny@Isce.ipsl.fr (A. Dapoigny), I.missiaen@unsw.edu.au (L. Missiaen), magnus.morth@su.se, (C. Mörth), per.andersson@nrm.se (P. Andersson). 


\section{Abstract}

${ }^{231} \mathrm{~Pa},{ }^{230} \mathrm{Th}$ and ${ }^{232} \mathrm{Th}$ were analyzed in filtered seawater $(\mathrm{n}=70)$ and suspended particles ( $\mathrm{n}$ = 39) collected along a shelf-basin transect from the Barents shelf to the Makarov Basin in the Arctic Ocean during GEOTRACES section GN04 in 2015. The distribution of dissolved ${ }^{231} \mathrm{~Pa}$ and ${ }^{230} \mathrm{Th}$ in the Arctic Ocean deviates from the linear increase expected from reversible scavenging. Higher ${ }^{232}$ Th concentrations were observed at the shelf, slope and in surface waters in the deep basin, pointing at lithogenic sources. Fractionation factors $\left(F_{\mathrm{Th} / \mathrm{Pa}}\right)$ observed at the Nansen margin were higher compared to $\mathrm{F}_{\mathrm{Th} / \mathrm{Pa}}$ in the central Nansen Basin, possibly due to the residual occurrence of hydrothermal particles in the deep central Nansen Basin. Application of a boundary scavenging model quantitatively accounts for the dissolved and particulate ${ }^{230}$ Th distributions in the Nansen Basin. Modeled dissolved ${ }^{231} \mathrm{~Pa}$ distributions were largely overestimated, which was attributed to the absence of incorporation of water exchange with the Atlantic Ocean in the model. ${ }^{231} \mathrm{~Pa} /{ }^{230} \mathrm{Th}$ ratios of the suspended particles of the Nansen Basin were below the ${ }^{231} \mathrm{~Pa} /{ }^{230} \mathrm{Th}$ production ratio, but top-core sediments of the Nansen margin and slope have high ${ }^{231} \mathrm{~Pa} /{ }^{230} \mathrm{Th}$-ratios, suggesting that scavenging along the Nansen margin partly acts as a sink for the missing Arctic ${ }^{231} \mathrm{~Pa}$.

Keywords: GEOTRACES, Protactinium, Thorium, Arctic Ocean, Boundary scavenging, 


\section{Introduction}

Particle reactive isotopes in the natural uranium and thorium decay series are useful tracers of particle flux and scavenging in the oceans (e.g. Edmonds et al., 2004; Roy-Barman, 2009; Rutgers van der Loeff and Berger, 1993). In seawater, ${ }^{231} \mathrm{~Pa}$ and ${ }^{230} \mathrm{Th}$ are produced at a constant rate by the decay of homogeneously distributed ${ }^{235} \mathrm{U}$ and ${ }^{234} \mathrm{U}$, respectively. Both ${ }^{231} \mathrm{~Pa}$ and ${ }^{230} \mathrm{Th}$ are particle reactive elements, which means that they get scavenged onto settling particles and removed from the water column to the sediments. However, due to differences in their particle reactivity, the ${ }^{231} \mathrm{~Pa} /{ }^{230} \mathrm{Th}$ ratio of seawater, marine particles and sediments often differs from that of the production ratio (Rutgers van der Loeff and Berger, 1993). The distribution and dispersion of ${ }^{231} \mathrm{~Pa}$ and ${ }^{230} \mathrm{Th}$ in the water column and their ratio in sediments are of interest for processes controlling spatial and temporal variations in ocean biogeochemistry. The difference in the chemical behavior of the two tracers can result in large scale deviation of the ${ }^{231} \mathrm{~Pa} /{ }^{230} \mathrm{Th}$ ratio of marine sediments compared to the production ratio of these nuclides in the overlying water column, with higher sedimentary ${ }^{231} \mathrm{~Pa} /{ }^{230} \mathrm{Th}$ ratios at ocean margin and lower ${ }^{231} \mathrm{~Pa} /{ }^{230} \mathrm{Th}$ to the inner ocean compared to the production ratio. Differences in particle concentration, composition and flux influence scavenging rates of ${ }^{231} \mathrm{~Pa}$ and ${ }^{230} \mathrm{Th}$ in the water column (Chase et al., 2002). Environments governed by high particle flux, such as ocean margins are very effective sinks for ${ }^{231} \mathrm{~Pa}$ and ${ }^{230} \mathrm{Th}$ (e.g. Scholten et al., 1995; Gdaniec et al., 2017). This process, usually referred to as boundary scavenging has previously been thought to be pronounced in the Arctic Ocean (Bacon et al., 1989; Cochran et al., 1995; Scholten et al., 1995). However, despite the contrasted particle fluxes over large shelf areas (receiving high river inputs) and the inner Arctic with its perennial sea ice cover, the ${ }^{231} \mathrm{~Pa} /{ }^{230} \mathrm{Th}$ ratio of arctic sediment does not vary much and is on average lower than the production ratio (e.g. Edmonds et al., 2004; Moran et al., 2005b). Not many studies have reported ${ }^{231} \mathrm{~Pa} /{ }^{230} \mathrm{Th}$ ratios slightly exceeding the production ratio (e.g. Luo and Lippold, 2015). The overall low ${ }^{231} \mathrm{~Pa} /{ }^{230} \mathrm{Th}$ ratios casted some doubts on mechanisms driving the boundary scavenging in the Arctic Ocean. While boundary scavenging does occur in the Arctic Ocean (Roy-Barman, 2009), the net export of ${ }^{231} \mathrm{~Pa}$ to the Atlantic Ocean through the Fram strait plays a key role in the $\mathrm{Pa}$ and Th budget of the Arctic Ocean (Edmonds et al., 2004; Hoffmann et al., 2013; Moran et al., 2005). However, the low vertical resolution, the relatively large analytical uncertainties and sometimes lack of particulate data limits the water column constraints on boundary scavenging in Arctic Ocean (Bacon et al., 1989; Cochran et al., 1995; Edmonds et al., 2004; Scholten et al., 1995) and more data are required for a proper modeling of boundary scavenging (Luo and Lippold, 2015).

In this study, dissolved and particulate ${ }^{231} \mathrm{~Pa},{ }^{230} \mathrm{Th}$, and ${ }^{232} \mathrm{Th}$ concentrations measured along GEOTRACES section GN04 in the Barents Sea, Nansen Basin, Amundsen 
Basin and Makarov Basin are presented. The objective was to explore the influence of boundary scavenging and shelf-basin interactions on the observed distribution of ${ }^{231} \mathrm{~Pa}$ and ${ }^{230} \mathrm{Th}$ in the Arctic Ocean. We revisit boundary scavenging modelling using a model adapted from Roy-Barman (2009) that we compared to the current dataset and used to constrain the scavenging behavior of $\mathrm{Pa}$ and Th between the Arctic margin and the inner ocean.

\section{Methods}

\subsection{Sampling}

Samples were collected on R/V Polarstern during expedition PS94 in 2015, at seven stations located in the Barents Sea, Nansen, Amundsen and Makarov Basins along the GEOTRACES GA04 section in the Arctic Ocean (Fig. 1). The samples were collected along a shelf-basin transect from the Barents shelf to the Makarov Basin to study the exchange between the margin and interior ocean. Stations 4, 161, 153 and 18 represent the shelf, station 32 represents the margin, while station 40, 50, 125 (Amundsen basin) and 101 (Makarov basin) represent the interior ocean.

Water samples were collected in 24 L Niskin ${ }^{\circledR}$ bottles mounted on a General Oceanic ${ }^{\circledR}$ rosette equipped with a Sea-Bird Electronics CTD system (SBE911plus). The CTD-system was equipped with sensors allowing measurements of salinity, temperature and transmission (Rabe et al., 2016; van Ooijen et al., 2016). For the analysis of dissolved ${ }^{231} \mathrm{~Pa}$, ${ }^{230} \mathrm{Th}$ and ${ }^{232} \mathrm{Th}$, $5 \mathrm{~L}$ of water were filtered directly from the Niskin bottles into sampling containers using Acropak500тм cartridges ( $0.45 \mu \mathrm{m}$ pore size), which were cleaned in between stations. After filtration, water samples were acidified using concentrated ultra-pure $\mathrm{HCl}(\sim 1 \mathrm{ml}$ of acid per 1 $L$ of seawater). Samples were stored in double plastic bags until analysis.

Particulate samples were collected using in-situ pumps (McLane and Challenger Oceanic) at six stations along the GA04 section (Fig. 1). Particles (0.8 $\mu \mathrm{m}$ pore size) were collected on Supor ${ }^{\circledR}$ polyethersulfone filters with a diameter of $142 \mathrm{~mm}$.

At two locations (N 84 6’ 51.64”, E $12^{\circ} 4 ` 11.69^{\prime \prime}$ and N 84 31.40”, E $11^{\circ} 6^{\prime} 11.43^{\prime \prime}$ ), "dirty ice" (ice rafted sediments incorporated into sea ice when it forms on the Arctic shelf) was collected from deck using a plastic spade and container.

At station 161, 32 and 101, surface sediment cores were collected using a Multi-corer (Fig. 1). The top (0-1 cm interval) of each core was analyzed for ${ }^{238} \mathrm{U},{ }^{234} \mathrm{U},{ }^{231} \mathrm{~Pa},{ }^{232} \mathrm{Th}$ and ${ }^{230}$ Th at LSCE. 

sediments and dirty ice

${ }^{231} \mathrm{~Pa},{ }^{230} \mathrm{Th}$ and ${ }^{232} \mathrm{Th}$ were determined by isotope dilution and mass spectrometry. Seawater samples were processed as described in (Gdaniec et al., 2017). For filtered particles, approximately $1 / 5$ (corresponding to $\sim 25$ - $200 \mathrm{~L}$ seawater) of the total filter material was cut onboard in a laminar flow bench and used to determine the concentrations of ${ }^{231} \mathrm{~Pa}$ and Th isotopes in suspended particles. The leaching of filter samples was performed at the Swedish Museum of Natural history followed by spiking and analysis at LSCE. The filters were submerged in $3 \mathrm{~N} \mathrm{HCl}$ and heated to $>50^{\circ} \mathrm{C}$ to wash the particles off the filters without dissolving the filters. The leachate, containing the suspended particles, was then dissolved in a mixture of concentrated $\mathrm{HNO}_{3}$ and $\mathrm{HF}$ following the method described in Gdaniec et al. (2017).

Surface sediments were dried and an aliquot $(0.2 \mathrm{~g})$ of crushed bulk sediment was spiked with ${ }^{233} \mathrm{~Pa},{ }^{229} \mathrm{Th}$ and ${ }^{236} \mathrm{U}$, followed by total dissolution in a $\mathrm{HNO}_{3}$ and $\mathrm{HF}$ mixture. $\mathrm{Pa}$, Th and $U$ were separated by anion exchange chromatography (Guihou et al., 2010).

The dirty ice samples were melted and particles were separated by centrifugation at the clean laboratory of Laboratoire des Sciences de l'Environnement Marin (LEMAR). Total dissolution of the particles ( $0.2 \mathrm{~g}$ ) was carried out at the Swedish Museum of Natural History using microwave oven digestion using $\mathrm{HF}, \mathrm{HNO}_{3}$ and $\mathrm{HCl}$ followed by spiking, chemical separation and analysis of ${ }^{231} \mathrm{~Pa},{ }^{230} \mathrm{Th}$ and ${ }^{232} \mathrm{Th}$ at Laboratoire des Sciences du Climat et de I’Environnement (LSCE).

${ }^{231} \mathrm{~Pa},{ }^{230} \mathrm{Th}$ and ${ }^{232} \mathrm{Th}$ concentrations in seawater, particles and sediment samples were analyzed at LSCE by Multi Collector Inductively Coupled Plasma Mass Spectrometry (MC-ICP-MS) on a Thermo Scientific ${ }^{T M}$ Neptune Plus ${ }^{T M}$ instrument equipped with an Aridus $\mathrm{II}^{\mathrm{TM}}$ desolvating nebulizer and a Jet interface (Burckel et al., 2015, Gdaniec et al., 2017).

Uranium concentrations in seawater were estimated using the bottle salinity measured from the CTD and the $U$-Salinity relationship in seawater $(U=(0.100$ * $S-0.326)$, Owens et al., 2011). The conservative behavior of uranium in the Arctic Ocean can be questioned due to the surface and mixed layer of the Arctic contain a significant portion of a mixture of river and ice melt water. However, in the study of Not et al. (2012) the investigators apply the $U$ vs. salinity relationship over a salinity range of $\sim 0-135$, and showed that the $U$ salinity relationship exhibits the conservative behavior over the entire range investigated.

Procedural blanks for seawater samples were determined by performing a complete chemical procedure on 3-11 bottles of $250 \mathrm{ml}$ of Milli-Q® water with each batch of samples. Total procedural blanks for seawater samples ranged between $7.3 \mathrm{pg}$ and $29.9 \mathrm{pg}$ for ${ }^{232} \mathrm{Th}$ (average $=15 \pm 6 \mathrm{pg}$ ), 0.07 and $8.42 \mathrm{fg}$ for ${ }^{230} \mathrm{Th}$ (average $=1.02 \pm 1.80 \mathrm{fg}$ ) and 0.05 and 0.26 
fg for ${ }^{231} \mathrm{~Pa}$ (average $=0.17 \pm 0.18 \mathrm{fg}$ ). These blanks were equivalent to $0.9-14 \%$ of the measured ${ }^{232} \mathrm{Th}, 0.2-21 \%$ of the measured ${ }^{230} \mathrm{Th}$ and $0.1-42 \%$ of the measured ${ }^{231} \mathrm{~Pa}$.

For particles, procedural blanks were prepared in the same way as for samples by using acid cleaned filters $\left(0.5 \mathrm{~N} \mathrm{HNO}_{3}\right)$ mounted onto the pump and deployed but not connected to the pumping system. Total procedural blanks ranged between $3.3 \mathrm{pg}$ and 29.1 pg for ${ }^{232} \mathrm{Th}$ (average $=4.3 \pm 1.2 \mathrm{pg}$ ), 0.02 and $0.36 \mathrm{fg}$ for ${ }^{230} \mathrm{Th}$ (average $=0.15 \pm 0.03 \mathrm{fg}$ ) and 0.004 and $0.7 \mathrm{fg}$ for ${ }^{231} \mathrm{~Pa}$ (average $=0.27 \pm 0.34 \mathrm{fg}$ ). These blanks were equivalent to $0.1-$ $16 \%$ of the measured ${ }^{232} \mathrm{Th}, 0.1-19 \%$ of the measured ${ }^{230} \mathrm{Th}$ and $0.1-89 \%$ of the measured ${ }^{231} \mathrm{~Pa}$

All measured ${ }^{231} \mathrm{~Pa}$ and ${ }^{230} \mathrm{Th}$ concentrations were corrected for the in-growth of ${ }^{231} \mathrm{~Pa}$ and ${ }^{230} \mathrm{Th}$ by uranium decay during the time period between sample collection and the U-Th/Pa separation. All uncertainties are expressed as 2 standard errors on the mean $\left(2 \sigma_{n}\right)$ including the propagated contribution from sample weighting, spike impurities, spike contributions, blank corrections and mass spectrometric measurements. Replicates for dissolved ${ }^{231} \mathrm{~Pa},{ }^{230} \mathrm{Th}$ and ${ }^{232} \mathrm{Th}$ concentrations were measured (Tab S1). It was initiated because the first analysis of ${ }^{230} \mathrm{Th}$ at $1000 \mathrm{~m}$ depth for station 32 seemed obviously overestimated. An additional aliquot of the $1000 \mathrm{~m}$ sample was analyzed and 2 additional samples (500 m depth at St. 32 and 40 ) were replicated to check the method reliability. They confirmed that the first analysis of ${ }^{230} \mathrm{Th}$ at $1000 \mathrm{~m}$ depth had suffered from contamination, but showed a good agreement (within or close to analytical uncertainties) for the other ${ }^{231} \mathrm{~Pa}$ and ${ }^{230} \mathrm{Th}$ measurements. The ${ }^{232} \mathrm{Th}$ replicates can vary by as much as $30 \%$ indicating small ${ }^{232} \mathrm{Th}$ contaminations, but it will have no significant impact on the discussion.

An inter-comparison of dissolved and particulate $\mathrm{Pa}$-Th measurements between LSCE and AWI at stations 101 and 125 is given in Fig. ES1. Seawater samples at station 101 (GEOTRACES crossover station of the USCGC Healy HLY1502 (GN01) and R/V Polarstern PS94 (GN04) cruises) and station 125 were duplicated and analyzed for dissolved ${ }^{231} \mathrm{~Pa},{ }^{230} \mathrm{Th}$ and ${ }^{232} \mathrm{Th}$ in order to provide an intercomparison between AWI and LSCE. These samples were obtained from the same casts, but not always the same bottle, so some differences in concentrations were expected (Fig. ES1). Concentrations of dissolved ${ }^{231} \mathrm{~Pa},{ }^{230} \mathrm{Th}$ and ${ }^{232} \mathrm{Th}$ at station 50 (Fig. 1) have been published in Valk et al., 2018 and will be used here to investigate the relationship between the Nansen margin and interior. Moreover, an intercomparison of dissolved and particulate Pa-Th measurements with AWI (Alfred Wegener

190 Institute), UMN (Minnesota University) and LDEO (Lamont Doherty Earth Observatory) at 191 station 101 is in progress. 
The Arctic Mediterranean, like the Mediterranean Sea, transforms and exports Atlantic water of lower density entering from the adjacent ocean into high density intermediate and deep waters. The Arctic Ocean comprises two major basins, the Amerasian Basin and the Eurasian Basin, separated by the Lomonosov Ridge (Fig. 1). The Eurasian Basin is divided into the Nansen and Amundsen Basin by the Gakkel Ridge, while the Amerasian Basin is separated by the Alpha-Mendeleyev Ridge into the Makarov and the Canada Basins (Fig. 1).

The inflow of Atlantic Water (AW) over the Barents Sea was recognized at stations 161 and 153 , where high salinity $(>35.1)$ and high temperatures $\left(\sim 2-7.6^{\circ} \mathrm{C}\right)$ were observed (Rabe et al., 2016) (Fig. ES2). Close to the Barents Sea shelf break (St. 04 and 18), the polar waters (Polar Mixed Layer and Halocline) were significantly colder $\left(\leq 0.8^{\circ} \mathrm{C}\right)$ and fresher $(\leq$ 34.8) compared to the inflow of AW (Fig. ES2). AW enters the central Arctic Ocean mainly by two branches; the Fram Strait Branch Water (FSBW) and the Barents Sea Branch Water (BSBW) (Rudels, 1994). The FSBW enters the Nansen Basin through the Fram Strait and then forms the Boundary current that flows around the Nansen Basin along the Gakkel Ridge (e.g. Rudels, 2009) (Fig. ES3). As AW enters the Arctic Basin, it encounters sea ice and the upper water masses cool $\left(-1.8^{\circ} \mathrm{C}\right)$ and become less saline ( 34.9 - 35.0) compared to underlying waters (Fig. ES2).

The BSBW flows over the Barents Sea shelf and enters the Nansen Basin through St. Anna Trough ( 1000 m depth), where limited exchange with FSBW occurs (e.g. Rudels, 2009) (Fig. ES3). At the eastern Siberian margin, the BSBW is divided into 3 branches: one branch flows into the Amundsen Basin while the second branch of the BSBW continues to flow towards the Fram Strait, as well as the ventilated intermediate water masses (Tanhua et al., 2009) (Fig. ES3). The third part of the BSBW prolongs into the Makarov Basin as part of the Arctic Ocean Boundary Current that travels anti-cyclonically around the Arctic Ocean (Rudels, 1994; Rudels et al., 2012).

In the Nansen Basin (St. 32 and 40), the warm FSBW was observed between 100 and $1000 \mathrm{~m}$ (Rabe et al., 2016) (Fig. ES2). In these waters, the Atlantic layer typically has maximum temperature of $\sim 2.5^{\circ} \mathrm{C}$ and the salinity ranges between 34.9 and 35.05 (Fig. ES2). Station 50 , in the central Nansen Basin is influenced by the return flow of colder $\left(-2^{\circ} \mathrm{C}\right)$ and less saline FSBW along the Gakkel Ridge (Rabe et al., 2016) (Fig. ES2).

The Eurasian Basin communicates with the Canada Basin through the boundary current that enters the Canada Basin north of Siberia and through the intra-Basin located at the central part of the Lomonosov Ridge, with a sill depth of 1850 m (Björk et al., 2007) (Fig. ES3). A reverse flow from the Makarov Basin to the Amundsen basin has also been identified (Björk et al., 2010, 2007) 
Above $1700 \mathrm{~m}$, stations 125 and 101 show similar water mass characteristics that fit to the BSBW (Rabe et al., 2016) (Fig. ES2). Below this depth range, the deep waters of the

232 Amerasian Basin are warmer and saltier compared to the Eurasian Basin Deep Water (EBDW)

233 (Fig. ES2) (e.g. Aagaard et al., 1981). The deep waters from the Eurasian Basin exit the Arctic 234 through the Fram Strait and contribute to the deeper layers in the Nordic Seas (e.g. Rudels, 235 2015).

\section{$236 \quad 3.2$ Dissolved and particulate ${ }^{232}$ Th concentrations}

237 Concentrations of dissolved ${ }^{232} \mathrm{Th}$ in the Arctic Ocean ranged between 11 and $205 \mathrm{pg} / \mathrm{kg}$ and 238 were generally decreasing with depth (Fig. 2). Elevated concentrations of ${ }^{232}$ Th were observed 239 close to the Nansen shelf break at station 04 and $18(72-205 \mathrm{pg} / \mathrm{kg})$ and in surface waters of 240 station $101(139-194 \mathrm{fg} / \mathrm{kg})$. Below $\sim 500 \mathrm{~m}$ depth, concentrations of dissolved ${ }^{232} \mathrm{Th}$ were 241 higher closer to the Nansen margin (24-80 pg/kg) compared to the Nansen interior (11 - 60 $\mathrm{pg} / \mathrm{kg}$ ) (Fig. 2).

Concentrations of particulate ${ }^{232}$ Th in the Barents Sea display elevated concentrations at depth, where concentrations up to $\sim 2500 \mathrm{pg} / \mathrm{kg}$ were observed at station 04 (Fig. 3). At the deep stations, particulate ${ }^{232} \mathrm{Th}$ ranged between $10 \mathrm{pg} / \mathrm{kg}$ and $\sim 80 \mathrm{pg} / \mathrm{kg}$, where lower concentrations were observed at the ocean interior (St. 101 and 50) compared to the margin (St. 32) (Fig. 3).

\subsection{Dissolved ${ }^{231} \mathrm{Paxs}$ and ${ }^{230} \mathrm{Th}_{\mathrm{xs}}$ concentrations}

Measured concentrations of ${ }^{231} \mathrm{~Pa}$ and ${ }^{230} \mathrm{Th}$ must be corrected for the presence of detrital components due to the presence of $U$ in lithogenic particles. The concentration of lithogenic $U$ is estimated from the measured concentrations of ${ }^{232} \mathrm{Th}$, which is entirely of lithogenic origin (Brewer et al., 1980). As $U$ is assumed to be at secular equilibrium in lithogenic phases, the unsupported ${ }^{231} \mathrm{~Pa}$ and ${ }^{230} \mathrm{Th}\left({ }^{231} \mathrm{~Pa}_{\mathrm{xs}}\right.$ and $\left.{ }^{230} \mathrm{Th}_{\mathrm{xs}}\right)$ produced solely by radioactive decay of dissolved U-isotopes can be calculated:

$$
{ }^{230} T h_{x s}={ }^{230} T h_{m}-{ }^{232} T h_{m} \times\left(\frac{{ }^{230} T h}{{ }^{232} T h}\right)_{\text {Litho }} \times \frac{M 230}{M 232}
$$

$$
{ }^{231} P a_{x S}={ }^{231} P a_{m}-{ }^{232} T h_{m} \times\left(\frac{{ }^{230} T h}{{ }^{232} T h}\right)_{\text {Litho }} \times\left(\frac{{ }^{235} U}{{ }^{238} U}\right)_{N a t} \times \frac{\lambda_{230}}{\lambda_{238}} \times \frac{\lambda_{235}}{\lambda_{231}} \times \frac{M 231}{M 232}
$$


1/137.88 (atom/atom) (Condon et al., 2010) and the $\left({ }^{230} T h{ }^{232} T h\right)_{\text {Litho }}$ was estimated from the average activity ratio $\left[{ }^{238} \mathrm{U} /{ }^{232} \mathrm{Th}\right]=0.6 \pm 0.3$. This range is relatively large compared to values used previously for the Arctic Ocean $\left(\left[{ }^{238} \mathrm{U} /{ }^{232} \mathrm{Th}\right]=0.6 \pm 0.1\right.$, Moran et al., 2005b). It allows covering the high value $\left(\left[{ }^{238} \mathrm{U} /{ }^{232} \mathrm{Th}\right] \approx 0.9\right)$ deduced from the ${ }^{230} \mathrm{Th} /{ }^{232} \mathrm{Th}\left(=4.75 \times 10^{-6} \mathrm{~mol} / \mathrm{mol}\right)$ measured in the dirty ice, as well as the low ratio $\left(\left[{ }^{238} \mathrm{U} / 232 \mathrm{Th}\right]=0.3\right)$ inferred from the filtered particles at station 04 to avoid "negative ${ }^{231} \mathrm{~Pa}_{\mathrm{xs}}$-values" in (see section 3.4). The secular equilibrium in the lithogenic fraction of marine sediment is at has been questioned due to the possible loss of ${ }^{234} \mathrm{U}$ (through ${ }^{234} \mathrm{Th}$, its parent isotope), ${ }^{230} \mathrm{Th}$ and ${ }^{231} \mathrm{~Pa}$ (through ${ }^{231} \mathrm{Th}$, its parent isotope) by a-recoil (Bourne et al., 2012). At present, it is unclear if this process is sufficient to explain the discrepancy between the 2 estimates of the $\left[{ }^{238} \mathrm{U} /{ }^{232} \mathrm{Th}\right]$ activity ratio presented here. Therefore, we conservatively consider the range $\left[{ }^{238} \mathrm{U} /{ }^{232} \mathrm{Th}\right]=0.6 \pm 0.3$ as possible and to propagate the resulting uncertainties. The same lithogenic corrections have been made for the dissolved concentrations of ${ }^{231} \mathrm{~Pa}$ and ${ }^{230} \mathrm{Th}$ at stations 50 and 125 measured by Valk et al., (2018).

$\lambda_{230}, \lambda_{231}, \lambda_{235}$ and $\lambda_{238}$ are the decay constants for ${ }^{230} \mathrm{Th}\left(\lambda_{230}=9.16 \times 10^{-6} \mathrm{y}^{-1}\right),{ }^{231} \mathrm{~Pa}$ $\left(\lambda_{231}=2.11 \times 10^{-5} \mathrm{y}^{-1}\right),{ }^{235} \mathrm{U}\left(\lambda_{235}=9.85 \times 10^{-10} \mathrm{y}^{-1}\right)$ and ${ }^{238} \mathrm{U}\left(\lambda_{238}=1.55 \times 10^{-10} \mathrm{y}^{-1}\right)$, respectively (Cheng et al., 1998; Condon et al., 2010). M230, M231 and M232 are the atomic masses of ${ }^{230} \mathrm{Th}(230.033 \mathrm{~g} / \mathrm{mol}){ }^{231} \mathrm{~Pa}(231.036 \mathrm{~g} / \mathrm{mol})$ and ${ }^{232} \mathrm{Th}(232.038 \mathrm{~g} / \mathrm{mol})$. The concentrations of ${ }^{231} \mathrm{~Pa}$ and ${ }^{230} \mathrm{Th}$ can be converted to radioactivity units $(\mu \mathrm{Bg} / \mathrm{kg})$ by using the conversion factors 0.5724 and 1.3110 , respectively. ${ }^{232}$ Th concentrations can be converted to $\mathrm{pmol} / \mathrm{kg}$ using the atomic mass of ${ }^{232}$ Th (232.038).

Higher lithogenic content was observed in particles and seawater collected at the shelf, margin and in bottom waters of the deep basins. On average, the lithogenic contribution ranged between 0.04 and $33 \%$ for dissolved ${ }^{231} \mathrm{~Pa}$, between 2.3 and $72 \%$ for particulate ${ }^{231} \mathrm{~Pa}$, between 0.3 and $34 \%$ for dissolved ${ }^{230}$ Th and between 1.0 and $58 \%$ for particulate ${ }^{230} \mathrm{Th}$.

In the deep Arctic Basin, the observed dissolved concentrations of ${ }^{231} \mathrm{~Pa}_{\mathrm{xs}}$ and ${ }^{230} \mathrm{Th}_{\mathrm{xs}}$ are increasing with depth until $\sim 2000 \mathrm{~m}$, followed by decreasing or invariant concentrations approaching the seafloor. This depletion at depth was more pronounced at the Nansen Basin stations $(32,40,50)$ compared to the Makarov Basin station (101). The depletion of ${ }^{230} \mathrm{Th}_{\mathrm{xs}}$ in the Nansen Basin was greater compared to the decrease of dissolved ${ }^{231} \mathrm{~Pa} \mathrm{xx}_{\mathrm{xs}}$ in waters below 2000 m depth (Fig. 2).

In the Makarov Basin, dissolved ${ }^{231} \mathrm{~Pa}_{\mathrm{xs}}$ ranged between 0.02 and $4.0 \mathrm{fg} / \mathrm{kg}$ and concentrations of dissolved ${ }^{230} \mathrm{Th}_{\mathrm{xs}}$ ranged between 0.9 and $27.9 \mathrm{fg} / \mathrm{kg}$. In contrast, lower concentrations of dissolved ${ }^{231} \mathrm{~Pa}_{\mathrm{xs}}(0.19-1.9 \mathrm{fg} / \mathrm{kg})$ and ${ }^{230} \mathrm{Th}_{\mathrm{xs}}(2.1-8.9 \mathrm{fg} / \mathrm{kg})$ were observed at the deep stations of the Eurasian Basin (Fig. 2).

In the Barents Sea, concentrations of dissolved ${ }^{231} \mathrm{~Pa}_{\mathrm{xs}}$ were lower in the polar waters of stations 04 and $18(0.1-0.2 \mathrm{fg} / \mathrm{kg})$ compared to the inflowing Atlantic Water stations 153 
and $161(0.23-0.6 \mathrm{fg} / \mathrm{kg})$, while the dissolved ${ }^{231} \mathrm{~Pa}_{\mathrm{xs}}$ in shallow waters $(<500 \mathrm{~m})$ over the slope (St 32) and in the Nansen Basin (stations 40 and 50) $\left({ }^{231} \mathrm{~Pa}_{\mathrm{xs}}=0.20-0.4 \mathrm{fg} / \mathrm{kg}\right.$ ) are intermediate between the Atlantic inflowing water (St. 153, 161) and close to Svalbard (St. 4). The distribution of dissolved ${ }^{230} \mathrm{Th}_{\mathrm{xs}}$ was similar for all four shelf stations $(0.5-1.99$ $\mathrm{fg} / \mathrm{kg}$ ) (Fig. 2) and generally lower compared to water at corresponding depth of the interior basin (2.3 - $3.8 \mathrm{fg} / \mathrm{kg})$ (Fig. 2).

At station 125, located in the Amundsen Basin, the water column distribution of dissolved ${ }^{231} \mathrm{~Pa}$ was similar compared to the stations located in the Nansen Basin, while concentrations of dissolved ${ }^{230}$ Th in the Nansen Basin (St. 32, 40, 50) were similar or higher compared to the distribution of dissolved ${ }^{230}$ Th from $500 \mathrm{~m}$ to $2000 \mathrm{~m}$ depth at station 125 (Fig. 2).

\subsection{Particulate ${ }^{231} \mathrm{Paxs}$ and ${ }^{230} \mathrm{Th}_{\mathrm{xs}}$ concentrations}

The filtered particles from station 04 (Tab. ES2) and the dirty ice (Tab. ES3) were used to determine the range of $\left[{ }^{238} \mathrm{U} /{ }^{232} \mathrm{Th}\right]$ activity ratios of the lithogenic material. There was a high abundance of lithogenic particles at station $04\left({ }^{232} \mathrm{Th}=46-2400 \mathrm{pg} / \mathrm{kg}\right)$ and these particles have low ${ }^{231} \mathrm{~Pa} /{ }^{232} \mathrm{Th}$ ratios that must be supported by a $\left[{ }^{238} \mathrm{U} /{ }^{232} \mathrm{Th}\right.$ ] activity ratio of $\sim 0.3$ (to avoid negative values of ${ }^{231} \mathrm{~Pa}_{\mathrm{xs}}$ ), a value that we take as the lower limit of the $\left[{ }^{238} \mathrm{U} /{ }^{232} \mathrm{Th}\right.$ ] activity ratio of the lithogenic material. Ice rafted sediments embedded in sea ice (called "dirty ice") are an important source of lithogenic particles in the Arctic Ocean (Pfirman and Thiede, 1987). As dirty ice is formed on the shelf, it may contain shelf sediments that have been incorporated into the ice as anchor ice or by sediment resuspension. This means that the dirty ice could contain some ${ }^{230} \mathrm{Th}_{\mathrm{xs}}$ that has been scavenged over the shelf. Here, the ${ }^{230} \mathrm{Th} /{ }^{232} \mathrm{Th}$ ratio $\left(=4.75 \times 10^{-6} \mathrm{~mol} / \mathrm{mol}\right)$ of dirty ice is supported by a $\left[{ }^{238} \mathrm{U} /{ }^{232} \mathrm{Th}\right]$ activity ratio of $\sim 0.9$, a value in good agreement with the estimate of the average continental crust suggesting that dirty ice is free of ${ }^{230} \mathrm{Th}_{\mathrm{xs}}$. Therefore, we take 0.9 as the upper limit of the $\left[{ }^{238} \mathrm{U} /{ }^{232} \mathrm{Th}\right.$ ] activity ratio of the lithogenic material.

Concentrations of particulate ${ }^{231} \mathrm{~Pa}_{\mathrm{xs}}$ and ${ }^{230} \mathrm{Th}_{\mathrm{xs}}$ in the Arctic Ocean generally display an increasing trend with depth. Particulate concentrations of ${ }^{231} \mathrm{~Pa}_{\mathrm{xs}}$ ranged between 0.0004 and $0.08 \mathrm{fg} / \mathrm{kg}$ and particulate ${ }^{230} \mathrm{Th}_{\mathrm{xs}}$ concentrations ranged between 0.001 and $5.6 \mathrm{fg} / \mathrm{kg}$. Elevated particulate ${ }^{231} \mathrm{~Pa}_{\mathrm{xs}}$ and ${ }^{230} \mathrm{Th}_{\mathrm{xs}}$ concentrations were observed close to the seafloor at stations 04, 153 and 161 and in deep waters of the Nansen and Makarov Basins (Fig. 3). Due to the high abundance of particulate ${ }^{232} \mathrm{Th}$ at station $04\left({ }^{232} \mathrm{Th}=46-2400 \mathrm{pg} / \mathrm{kg}\right)$, it was not possible to estimate the unsupported particulate ${ }^{231} \mathrm{~Pa}_{\mathrm{xs}}$ concentrations for this station (see above). 
In the interior Nansen (Station 50), the distribution of particulate ${ }^{231} \mathrm{~Pa}_{\mathrm{xs}}$ and ${ }^{230} \mathrm{Th}_{\mathrm{xs}}$ displayed an increase with depth until $\sim 3000 \mathrm{~m}$, followed by a decrease in particulate concentrations approaching the seafloor. At station 32, concentrations of particulate ${ }^{230} \mathrm{Th}_{\mathrm{xs}}$ ranged between 0.02 and $5.6 \mathrm{fg} / \mathrm{kg}$, which was similar to concentrations observed at station $50(0.28-5.9 \mathrm{fg} / \mathrm{kg})$. In contrast, particulate ${ }^{231} \mathrm{~Pa}_{\mathrm{xs}}(>2000 \mathrm{~m})$ was lower at the slope $(0.05-$ $0.08 \mathrm{fg} / \mathrm{kg}$ ) compared to the interior $(0.13-0.18 \mathrm{fg} / \mathrm{kg})$ (Fig. 3).

The distribution of particulate ${ }^{230} \mathrm{Th}_{\mathrm{xs}}$ observed at station 101 was very similar to the slope and interior of the Nansen Basin, while, below $1500 \mathrm{~m}$, the particulate ${ }^{231} \mathrm{~Pa}_{\mathrm{xs}}$ concentrations were lower in the Makarov Basin compared to the stations located in the Nansen Basin (Fig. 3). As this manuscript was already submitted, the intercomparison work revealed that the particulate ${ }^{231} \mathrm{~Pa}$ concentrations at station 101 are $\sim 50 \%$ lower than at the nearby station of the USCGC Healy HLY1502 (GN01) cruise in 2015 (while particulate Th isotopes are essentially similar at the 2 stations). Therefore, the interpretation of particulate $\mathrm{Pa}$ data requires caution.

Before we can compare particulate ${ }^{230} \mathrm{Th}_{\mathrm{xs}}$ and ${ }^{231} \mathrm{~Pa}_{\mathrm{xs}}$ in the water column with measurements in the surface sediment, we must first evaluate if an age correction is required for the sediment samples, as the sedimentation rate in the Arctic Ocean can be very low. Sedimentation rate estimates in the Makarov Basin range from 0.4 to $4 \mathrm{~cm} / \mathrm{ky}$ (e.g. Nowaczyk et al., 2001). It corresponds at most to a mean age of $1.2 \mathrm{ky}$ for the $1^{\text {st }} \mathrm{cm}$ of the sediment core, so that it is not necessary to correct the ${ }^{231} \mathrm{~Pa}_{\mathrm{xs}} /{ }^{230} \mathrm{Th}_{\mathrm{xs}}$ ratio for radioactive decay in the sediment. The higher sedimentation rates encountered over the Barents Sea and slope make age corrections negligible (Ivanova et al., 2002). We have determined the ${ }^{238} \mathrm{U}$ and ${ }^{234} \mathrm{U}$ content of the 3 sediments (Tab. ES3). The $\left[{ }^{234} \mathrm{U} / 238 \mathrm{U}\right]$ activity ratio of the 3 sediments is slightly below equilibrium suggesting the absence of seawater derived $U$, in agreement other arctic sediments (Hillaire-Marcel et al., 2017). Hence, we can estimate the [ $\left.{ }^{231} \mathrm{~Pa}_{\mathrm{xs}} /{ }^{230} \mathrm{Th}_{\mathrm{xs}}\right]$ activity ratio more precisely than based on the $\left[{ }^{238} \mathrm{U} /{ }^{232} \mathrm{Th}\right]$ range determined for the suspended particles.

\subsection{The Fractionation factor}

The fractionation factor $\left(\mathrm{F}_{\mathrm{Th} / \mathrm{Pa}}\right)$ was calculated as follows:

Fractionation factors obtained in this study ranged between 2.7 and 25.4 (Fig. 4). They are comparable to values reported from other ocean basins (e.g. Hayes et al., 2015a; Moran et al., 2002, 2001; Scholten et al., 2008). The distribution of $\mathrm{F}_{\mathrm{Th} / \mathrm{Pa}}$ with depth was rather constant (Fig. 4). Below 1000 m depth, fractionation factors were consistently lower at station 
50 in the interior of the Nansen Basin (2.7 - 13.3) compared to the Nansen margin (3.7 - 22.3) and the Makarov Basin (7.2 - 25.4) (Fig. 4).

\section{Discussion}

\section{1 ${ }^{230} \mathrm{Th}_{\mathrm{xs}}$ and ${ }^{232} \mathrm{Th}$ scavenging in the Arctic Ocean}

Early studies of ${ }^{210} \mathrm{~Pb}_{\mathrm{xs}}$ and ${ }^{230} \mathrm{Th}_{\mathrm{xs}}$ in Arctic sediments highlighted that their inventory in the sediments exceeded the supply from the overlying water column near the slopes and shelves and were greater at the margins compared to the interior basins (Huh et al., 1997; Smith et al., 2003). This process, usually referred to as boundary scavenging was expected to be pronounced in the Arctic Ocean due to the high proportion of shelf areas with the associated high particle flux versus the low particle flux regions in the ice-covered interior basins (Bacon et al., 1989; Cochran et al., 1995; Edmonds et al., 2004; Scholten et al., 1995). Early studies estimated the Th scavenging rates using a simple 1D production-vertical scavenging model (Bacon et al., 1989; Edmonds, 1998; Scholten et al., 1995), but this view was later challenged to include the effect of lateral transport, the effect of deep water ventilation (Scholten et al., 1995) and boundary scavenging (Roy-Barman, 2009). Box-modelling using sedimentary and dissolved ${ }^{230} \mathrm{Th}_{\mathrm{xs}}$ and ${ }^{231} \mathrm{~Pa}_{\mathrm{xs}}$ data suggests that $\sim 90 \%$ of the in-situ produced ${ }^{230} \mathrm{Th}_{\mathrm{xs}}$ was removed within the Arctic Ocean by particle scavenging and that a large fraction of the scavenged ${ }^{230} \mathrm{Th}_{\mathrm{xs}}$ was removed by boundary scavenging along the Arctic margins (Moran et al., 2005, Roy-Barman, 2009). The dataset presented here will be used to revisit our understanding of the scavenging processes in the Arctic Ocean. We start the discussion with ${ }^{230} \mathrm{Th}$ because it is highly particle reactive (relative to $\mathrm{Pa}$ ) and currently used to study and identify variations in scavenging intensity (e.g. Roy-Barman, 2009; Hayes et al., 2015).

\subsubsection{The Makarov Basin}

When lateral transport can be neglected, the 1D reversible scavenging model predicts a linear increase of both dissolved ${ }^{230} \mathrm{Th}_{\mathrm{xs}}\left({ }^{230} \mathrm{Th}_{\mathrm{xs}-\mathrm{d}}\right)$ and particulate ${ }^{230} \mathrm{Th}_{\mathrm{xs}}\left({ }^{230} \mathrm{Th}_{\mathrm{xs}-\mathrm{p}}\right)$ concentrations with depth and consequently produces a constant ${ }^{230} \mathrm{Th}_{\mathrm{xs}-\mathrm{p}} / 230 \mathrm{Th}$ xs-d ratio throughout the water column (Bacon and Anderson, 1982). Among all stations reported here, these conditions seem best fulfilled at station 101 in the Makarov Basin, particularly above 2000 m depth (Fig. 2 and 3). Station 101 is located in the Makarov Basin at high latitude isolated from continental margins. Therefore St. 101 can be used as a reference station to evaluate the effect of continental margins on the scavenging in the interior ocean. Neglecting horizontal transport, 
403 the ${ }^{230} \mathrm{Th}_{\mathrm{xs}-\mathrm{p}}$ concentration is a function of the settling rate $(S)$ of small particles and of the water

404 depth (h):

405

$406 \quad S=\frac{P_{230 T h} \times h}{{ }^{230} T h_{x s-p}}$

407

408

409

410

411

412

413

414

415

416

417

418

419

420

421

422

423

424

425

426

427

428

429

430

431

432

433

434

435

436

where the $P_{230 T h}$ is the production rate of ${ }^{230} \mathrm{Th}$ in the water column $(0.56 \mathrm{fg} / \mathrm{kg} / \mathrm{y})$. The settling rate $(S)$ of particles $(>0.8 \mu \mathrm{m})$ in the Makarov Basin ranged between $340-440 \mathrm{~m} / \mathrm{y}$, which is consistent with earlier estimates in the central Arctic Ocean (e.g. Edmonds et al., 2004; Scholten et al., 1995) and very close to new estimates e.g. $S=434 \mathrm{~m} / \mathrm{y}$ (Rutgers Van Der Loeff et al., 2018) However, it may represent an upper limit for the particle settling speed in the central Arctic, because this calculation neglects the possible role of boundary scavenging (Roy-Barman, 2009). The scavenging residence time of ${ }^{230} \mathrm{Th}_{\mathrm{xs}}(\sim 55 \mathrm{y})$ is much shorter than the water ventilation residence time in the Makarov Basin (e.g. Scholten et al., 1995). Since particle fluxes in the Makarov Basin are low and the water residence time is high, dissolved ${ }^{230} \mathrm{Th}_{\mathrm{xs}}$ concentrations have more time to build up by the decay of uranium and stay in solution (Fig. 2). The particulate/total ratio of ${ }^{230} \mathrm{Th}_{\mathrm{xs}}$ is relatively low (6-16\%) and tends to increase with depth at station 101 (Fig. 5).

Below $2000 \mathrm{~m}$ depth, dissolved ${ }^{230} \mathrm{Th}_{\mathrm{xs}}$ displayed more invariant concentrations followed by decreasing concentrations approaching the seafloor (Fig. 2). The ventilation of the deep Arctic could contribute to produce such concave profiles (Scholten et al., 1995). However, the ventilation age of the deep Makarov Basin is hundreds of years, which is much longer compared to the ${ }^{230}$ Th scavenging residence time (e.g. Rutgers van der Loeff et al., 2018). These depleted concentrations of dissolved ${ }^{230} \mathrm{Th}_{\mathrm{xs}}$ and ${ }^{232} \mathrm{Th}$ close to the seafloor were accompanied with elevated concentrations of particulate ${ }^{230} \mathrm{Th}_{\mathrm{xs}}$ and ${ }^{232} \mathrm{Th}$ (Fig. 3), suggesting enhanced removal of dissolved ${ }^{230} \mathrm{Th}_{\mathrm{xs}}$ close to the seafloor. No benthic nepheloid layer was detected by transmission (Fig. ES4). However, even a slight increase in resuspended sediments (not detectable by the transmissometer) may be sufficient to enhance scavenging and removal of dissolved ${ }^{230} \mathrm{Th}$ close to the seafloor.

\subsubsection{The Eurasian Basin}

A sharp depletion of ${ }^{230} \mathrm{Th}_{\mathrm{xs}}$ observed in deep waters $(>2000 \mathrm{~m}$ ) of the Nansen was recently attributed to removal of ${ }^{230} \mathrm{Th}_{\mathrm{xs}}$ related to release of dissolved iron from hydrothermal vents at the Gakkel ridge (Valk et al., 2018). Therefore, the following discussion will mainly be divided into water masses above and below $2000 \mathrm{~m}$ depth. 


\subsubsection{Waters above $2000 \mathrm{~m}$}

438 On the Barents shelf, the temperature and salinity at station 153 and 161 clearly indicate the inflow of saltier and warmer AW (Fig. ES2). As a consequence, the dissolved ${ }^{230} \mathrm{Th}_{\mathrm{xs}}$ concentrations (Fig. 2) compare well to surface concentrations from the northern Atlantic Ocean (Hayes et al., 2015a). Close to the seafloor at station 153 and 161 elevated particulate ${ }^{230} \mathrm{Th}_{\mathrm{xs}}$ and ${ }^{232} \mathrm{Th}$ concentrations were observed (Fig. ES2). The increased particulate fraction of ${ }^{230} \mathrm{Th}_{\mathrm{xs}}$ at the bottom of the water column accompanied with reduced dissolved ${ }^{230} \mathrm{Th}_{\mathrm{xs}}$ indicates bottom scavenging over the shelf (Fig. 2 and 3). The low beam transmission (300 $450 \mathrm{~m}$ depth) reflects resuspension of bottom sediments resulting in enhanced scavenging (Fig. ES4). This probably happens due to the inflow of AW over the Barents Sea shelf which disrupts the sediments close to the seafloor (Lukashin and Shcherbinin, 2007).

At stations 04 and 18, the polar waters was less salty and colder compared to the Atlantic inflow, suggesting influence of ice melt and runoff close to the coast of Svalbard (Fig. 3). This was also reflected by the low beam transmission in the surface and bottom waters over the Barents shelf, indicating the presence of suspended particulate material (Fig. ES4). In addition, extremely high concentrations of particulate ${ }^{232} \mathrm{Th}$ (up to $\sim 2400 \mathrm{pg} / \mathrm{kg}$ ) and elevated concentrations of dissolved ${ }^{232} \mathrm{Th}(100-200 \mathrm{pg} / \mathrm{kg})$ were observed at station 04 and 18 , suggesting that the particulate material is dominated by lithogenic inputs and partial dissolution of these particles (Fig. 2). Nevertheless, the dissolved ${ }^{230} \mathrm{Th}_{\mathrm{xs}}$ concentrations at stations 04 and 18 compare well with those of stations 153 and 161 suggesting that the water flow rate does not leave enough time for net scavenging to occur.

Station 32 and 40 are located within the FSBW, where the modified Atlantic inflow $\left(\sim 2.5^{\circ} \mathrm{C}\right)$ can be recognized between $\sim 100$ and $1000 \mathrm{~m}$ depth, followed by colder and less salty deep waters (Fig. ES2). Concentrations of dissolved ${ }^{230} \mathrm{Th}_{\mathrm{xs}}$ in surface waters at station 32 and $40(2.3-2.7 \mathrm{fg} / \mathrm{kg})$ were within the range but on the high side of North Atlantic ${ }^{230} \mathrm{Th}_{\mathrm{xs}}=0.76$ $-3.4 \mathrm{fg} / \mathrm{kg}$, Hayes et al., 2015) and Norwegian Sea $\left({ }^{230} \mathrm{Th}_{\mathrm{xs}}=0.6-2.3 \mathrm{fg} / \mathrm{kg}\right.$, Moran et al., 1995) values.

At station 32 and 40, dissolved ${ }^{230} \mathrm{Th}_{\mathrm{xs}}$ increases linearly with depth until $\sim 1500 \mathrm{~m}$ and then becomes constant (Fig. 2). This departure from the equilibrium profile suggests the possibility of enhanced scavenging at the margin. By contrast, Station 50 (Valk et al., 2018) is located within the return flow of the FSBW (Fig. ES2 and ES3). Dissolved ${ }^{230}{ }^{23} h_{x s}$ concentrations increase linearly down to $2000 \mathrm{~m}$ and they are higher than at station 32 and 40 indicating a lower scavenging rate. Surprisingly, the distribution of particulate ${ }^{230}{ }^{2} h_{x s}$ was very similar at stations 32 and 50 (and also at station 101) (Fig. 3). 
Elevated concentrations of particulate ${ }^{232} \mathrm{Th}$ at the margin (St. 32) compared to the inner ocean (St. 50) are likely due to the advection of shelf waters (St. 4) transporting ${ }^{232} \mathrm{Th}$ into the interior basin.

The dissolved ${ }^{230} \mathrm{Th}_{\mathrm{xs}}$ concentrations were considerably lower in the Amundsen basin (station 125) compared to the Makarov basin (station 101) (Fig. 2), as shown previously (Scholten et al., 1995; Valk et al., 2018). This reflects the large difference in water residence times between the Makarov and Amundsen Basins (Schlosser et al., 1997), where the longer water residence time in the Makarov Basin allows the concentrations of ${ }^{230} \mathrm{Th}_{\mathrm{xs}}$ to build up over time by the decay of $U$, whereas waters from the Amundsen Basin were submitted to boundary scavenging while flowing along the eastern Siberian margin.

Except the surface samples $(<100 \mathrm{~m})$, the dissolved ${ }^{230} \mathrm{Th}_{\mathrm{xs}}$ concentrations are significantly lower in the Nansen and Amundsen Basins (St. 50, 40, 32 125) compared to the Makarov Basin (St. 101). Within the Eurasian Basins (above $2000 \mathrm{~m}$ ), a horizontal gradient of dissolved ${ }^{230} \mathrm{Th}_{\mathrm{xs}}$ content between stations 125, 32, 40 and 50 was observed (Fig. 2). At station 50 , dissolved ${ }^{230} \mathrm{Th}_{\mathrm{xs}}$ concentrations were highest, followed by intermediate concentrations at the Nansen margin (St. 32, 40) and the lowest dissolved ${ }^{230} \mathrm{Th}_{\mathrm{xs}}$ were observed at station 125. This suggests that ${ }^{230} \mathrm{Th}_{\mathrm{xs}}$ is scavenged along the boundaries as the dissolved ${ }^{230} \mathrm{Th}_{\mathrm{xs}}$ is decreasing towards the margin. The water at station 125 has probably experienced more scavenging on the Kara and Laptev shelf compared to the Barents shelf. Another possible reason for the low ${ }^{230} \mathrm{Th}_{\mathrm{xs}}$ concentrations observed at 125 is scavenging onto particles carried by the TPD (Trans Polar Drift) (Charette, pers. com.).

\section{Below 2000 m}

Below $2000 \mathrm{~m}$, the ${ }^{230} \mathrm{Th}_{\mathrm{xs}}$ concentrations are relatively constant and identical within the Eurasian Basin. The sharp decrease at station 50 is clearly due to hydrothermal scavenging (Valk et al., 2018). In 2015, there was no sign of a strong hydrothermal activity in the beam transmission data suggesting that the hydrothermal event was over at the time of sampling and that the hydrothermal plume had faded away (Fig. ES4). The major part of the hydrothermal plume in the basin is expected to be transported out of the Nansen Basin along the Gakkel Ridge directly towards Fram Strait (Fig. ES3). Therefore, the distribution of dissolved ${ }^{230} \mathrm{Th}_{\mathrm{xs}}$ at stations 32,40 and 125 are not directly downstream of station 50 and their ${ }^{230} \mathrm{Th}_{\mathrm{xs}}$ do not necessarily represent hydrothermal scavenging conditions. Valk et al., (2018) identified hydrothermal plume water by their high dissolved Fe content. The dissolved $\mathrm{Fe}$ content of the deep waters at station 32 are higher than at station 50: it does not correspond 
to an hydrothermal source, but to sediment resuspension at the slope as a source of dissolved Fe (Klunder et al., 2012, Rijkenberg et al., 2018).

An additional argument for deep enhanced scavenging comes from ${ }^{232} \mathrm{Th}$. In general, dissolved ${ }^{232}$ Th concentrations increases with depth in the deep ocean (e.g. Moran et al., 2002, Scholten et al., 2008, Okubo et al., 2013). In the present study, ${ }^{232}$ Th decrease with depth, a feature that was already observed in the Arctic (Edmonds et al., 2004), but remained unexplained. The lack of increasing dissolved ${ }^{232} \mathrm{Th}$ concentrations towards the seafloor suggests enhanced bottom scavenging. The lowest dissolved ${ }^{232} \mathrm{Th}$ in the deep basins occurs at station 50 suggesting the involvement of scavenging by the hydrothermal plume. However, low deep dissolved ${ }^{232} \mathrm{Th}$ is also found in the Makarov Basin, where scavenging by a hydrothermal plume is not suspected. Note that the higher concentrations at station 32 do not necessarily represent a lower scavenging rate because a high scavenging rate can be balanced by a high input flux by particle resuspension/dissolution as suggested by the relatively low beam transmission and high particulate ${ }^{232} \mathrm{Th}$ at this station.

\section{The particulate fraction}

Despite different dissolved ${ }^{230} \mathrm{Th}_{\mathrm{xs}}$ profiles at stations 32, 50 (Nansen Basin) and 101 (Makarov Basin), the particulate ${ }^{230} \mathrm{Th}_{\mathrm{xs}}$ concentrations above $2500 \mathrm{~m}$ depth were similar at these stations (Fig. 3). By contrast, particulate ${ }^{232}$ Th concentrations were higher at station 32 compared to stations 50 and 101, highlighting the role of the continental margins in providing high levels of particulate matter into the low productivity interior ocean.

The particulate fraction of ${ }^{230} \mathrm{Th}_{\mathrm{xs}}$ increases with depth at stations 32 and 50 from $1 \%$ to $45 \%$ with a local maximum (20\%) around $200 \mathrm{~m}$ (Fig. 5). This subsurface maximum particulate fraction can be related to the high ${ }^{230} \mathrm{Th}_{\mathrm{xs}}$ particulate fractions associated to the bottom nepheloid layers on the shelf at station 153 and 04. Despite the high concentrations of particulate ${ }^{230} \mathrm{Th}_{\mathrm{xs}}$ in the Makarov Basin, the ${ }^{230} \mathrm{Th}_{\mathrm{xs}}$ particulate fractions are higher at stations 32 and 50 because the dissolved ${ }^{230} \mathrm{Th}_{\mathrm{xs}}$ concentrations are much lower in the Nansen Basin compared to the Makarov Basin. At station 32 and 101, the increased particulate fraction of ${ }^{230} \mathrm{Th}_{\mathrm{xs}}$ at the bottom of the water column accompanied with reduced dissolved ${ }^{230} \mathrm{Th}_{\mathrm{xs}}$ indicates bottom scavenging in deep waters of the open basin as it was already observed over the shelf

535 (Fig. 2 and 3). At station 50, the increased ${ }^{230} \mathrm{Th}_{\mathrm{xs}}$ particulate fraction of the bottom waters is

536 the relic of a hydrothermal plume induced scavenging event, possibly at a stage where the steady state situation is being achieved again (Valk et al., 2018). 
540 Several features listed in previous sections of this paper (increasing ${ }^{230} \mathrm{Th}_{\mathrm{xs}}$ particulate fraction with depth; decreasing dissolved ${ }^{230} \mathrm{Th}_{\mathrm{xs}}$ content in the deepest waters of the ocean margin) are not consistent with the 1D scavenging models that predict a linear increase of dissolved and particulate ${ }^{230} \mathrm{Th}_{\mathrm{xs}}$ concentrations with depth and a constant ${ }^{230} \mathrm{Th}_{\mathrm{xs}}$ particulate fraction with depth (e.g. Bacon and Anderson, 1982, Roy-Barman et al., 1996). They are not consistent with the boundary scavenging model of Roy-Barman (2009) either, because this model predicts a rather linear increase of dissolved ${ }^{230} \mathrm{Th}_{\mathrm{xs}}$ with depth at the margin and a constant ${ }^{230} \mathrm{Th}_{\mathrm{xs}}$ particulate fraction with depth. This is certainly due to an oversimplification of the particle dynamics: particles were assumed to have a constant vertical flux and their transport between the margin and the ocean interior was neglected. To overcome these assumptions, we propose a boundary scavenging model where particles are introduced both at the ocean surface and also throughout the water column at the margin (hypothesis 1) and where particles are transported between the margin and the ocean interior (hypothesis 2). The input of particles at all depths of the ocean margin can be viewed as a result of nepheloid layers on the shelf or on the slope and/or to the chemical evolution of particles as they settle through the water column (precipitation of Fe-Mn oxyhydroxides at depth for example). A key point is that the particles introduced at depth are assumed to be free of ${ }^{230} \mathrm{Th}_{\mathrm{xs}}$ and ${ }^{231} \mathrm{~Pa}_{\mathrm{xs}}$ when they are introduced in the water column, so that the input of particles will not be associated with an input of ${ }^{230} \mathrm{Th}_{\mathrm{xs}}$. and ${ }^{231} \mathrm{~Pa}_{\mathrm{xs}}$ (hypothesis 3 ). This means that the particles are not merely resuspended local bottom sediments, which are known to contain ${ }^{230} \mathrm{Th}_{\mathrm{xs}}$. Instead, we hypothesize that nepheloid layers flow downward as turbidity currents along the slope with no or little mixing with surrounding waters so that they may not scavenge ${ }^{230}$ Th until they detach from the slope. Only then, particles spread and scavenge ${ }^{230} \mathrm{Th}_{\mathrm{xs}}$ from the deep waters. This view differs from Rutgers van der Loeff and Boudreau (1997), who assumed equilibration between seawater and particles. Hypothesis (3) is required because a dissolved ${ }^{230} \mathrm{Th}_{\mathrm{xs}}$ depletion compared to the equilibrium profile cannot be produced by resuspension of sediments that would already be "equilibrated" with overlying seawater. Hypothesis (3) is crucial for creating a water column ${ }^{230} \mathrm{Th}_{\mathrm{xs}}$ profile as observed in this study. Transport of particles between the margin and the inner ocean (hypothesis 2) allows that most particles in the ice-covered central Arctic are advected from the margins.

\subsubsection{Transport of water}

572 In this box model, the Arctic Ocean is divided into 2 boxes: the ocean margin and the ocean interior (Fig. 6). The water volumes of the margin and of the ocean interior are $V_{m}$ and $V_{i}\left(m^{3}\right)$ 
574 (Jakobsson, 2002). These 2 boxes exchange a total flux of water $\mathrm{F}\left(\mathrm{m}^{3} / \mathrm{s}\right)$. For simplicity, we 575 assume that the water flows horizontally between the boxes. Vertical mixing and ventilation of

576

577

578

579

580

581

582

583

584

585

586

587

588

589

590

591

592

593

594

595

596

597 water by inputs through Fram strait and Barents Sea are neglected. Hence, at any depth in the water column the residence time of the water with respect to horizontal exchange is $\tau_{\mathrm{m}}=\mathrm{V}_{\mathrm{m}} / \mathrm{F}$ at the margin and $\tau_{i}=V_{i} / F$ at the ocean interior (Tab. 1). The time constant associated to water transport are $k_{m}=1 / \tau_{m}$ and $k_{i}=1 / \tau_{i}$. The time constant associated with water exchange between the ocean margin and the ocean interior are $k_{m}=1 / \tau_{m}$ for the ocean margin and $k_{i}=1 / \tau_{i}$ for the ocean interior.

\subsubsection{Particle transport}

In this study, the concentration of particles was not measured. The particle concentration is embedded in the dissolved-particulate partition coefficient $K$, introduced in the following section. We scale the impact of particle concentration on the partition coefficient $K$ with a parameter $m$ assumed to be proportional to the particulate concentration:

$$
m=P(z) / P^{m}(0)
$$

where $P$ is the particle concentration (at the margin or in the ocean interior) and $P^{m}(0)$ is the particle concentration in the surface water of the ocean margin. Hence, $m^{m}=1$ in the surface water of the ocean margin and $\mathrm{m}$ is proportional to the particle concentration elsewhere.

The conservation equations for $m^{m}$ and $m^{i}$ at the ocean margin and in the inner ocean include particle production throughout the water column at the margin (hypothesis 1) and particle transport between the margin and the inner ocean (hypothesis 2 ) and are given by:

$$
\begin{aligned}
& \frac{d m^{m}}{d t}=-S^{m} \frac{d m^{m}}{d z}+k_{m}\left(m^{i}-m^{m}\right)+\mu \times m^{m} \\
& \frac{d m^{i}}{d t}=-S^{i} \frac{d m^{i}}{d z}+k_{i}\left(m^{m}-m^{i}\right)
\end{aligned}
$$

where $S^{m}$ and $S^{i}$ are the settling velocities of the particles at the margin and in the inner ocean. They are both assumed to be constant with depth. We expect higher particle settling rates at the margin compared to the interior due to increased production and the associated particle flux (Anderson et al., 1983). $\mu$ is an arbitrary parameter aimed to produce an exponential increase of the particle concentration in the deep waters. $\mu$ operates as if (1) increasing turbulence towards the seafloor and increases the particle concentration by formation of nepheloids and/or (2) a diffusive flux of dissolved Manganese (Mn) from the 
605

606

607

608

609

610

611

612

613

614

615

616

617

618

619

620

621

622

624

625

626

627

628

629

630

sediment which allows precipitation of $\mathrm{Mn}$ oxides (that scavenges $\mathrm{Pa}$ and $\mathrm{Th}$ ) towards the sea floor. Assuming a steady state, we obtain:

$$
\begin{aligned}
& \frac{d m^{m}}{d z}=\frac{k_{m}}{s^{m}}\left(m^{i}-m^{m}\right)+\frac{\mu}{s^{m}} \times m^{m} \\
& \frac{d m^{i}}{d z}=\frac{k_{i}}{s^{i}}\left(m^{m}-m^{i}\right)
\end{aligned}
$$

Bulk dissolution of particles was not considered. The observed increasing particulate ${ }^{230} \mathrm{Th}$ fraction with depth points to an addition of particles with depth rather than a significant dissolution with depth, which would induce a concave shaped ${ }^{230}$ Th profile (Roy-Barman et al., 1996). Moreover, there is no direct constraint on the particle dissolution in the present study.

\subsubsection{Transport of ${ }^{230} \mathrm{Th}_{\mathrm{xs}}$ and ${ }^{231} \mathrm{~Pa} \mathrm{xs}$}

In each box, ${ }^{230} \mathrm{Th}$ and ${ }^{231} \mathrm{~Pa}_{\mathrm{xs}}$ are produced by in-situ decay of $\mathrm{U}$ at a constant rate $P$. The produced ${ }^{230} \mathrm{Th}$ and ${ }^{231} \mathrm{~Pa}_{\mathrm{xs}}$ are then transported towards the seafloor by reversible scavenging onto sinking particles and transported horizontally by the flow of water (Fig. 6). Considering the long half-life of ${ }^{230} \mathrm{Th}(75000 \mathrm{y})$ and ${ }^{231} \mathrm{~Pa}$ (32 $700 \mathrm{y}$ ), the radioactive decay of the two isotopes was neglected. Dissolved and particulate concentrations are noted as $C_{d}^{m}$ and $C_{p}^{m}$ for the margin and $C_{d}^{i}$ and $C_{p}^{i}$ for the ocean interior. The conservation equation of total ${ }^{230} \mathrm{Th}$ is given by:

The ocean margin:

$\frac{d\left(C_{d}^{m}+C_{p}^{m}\right)}{d t}=-S^{m} \frac{d C_{p}^{m}}{d z}+k_{m}\left(\left[C_{d}^{i}+C_{p}^{i}\right]-\left[C_{d}^{m}+C_{p}^{m}\right]\right)+P_{230}$

The ocean interior:

$\frac{d\left(C_{d}^{i}+C_{p}^{i}\right)}{d t}=-S^{i} \frac{d C_{p}^{i}}{d z}+k_{i}\left(\left[C_{d}^{m}+C_{p}^{m}\right]-\left[C_{d}^{i}+C_{p}^{i}\right]\right)+P_{230}$

At the margin (equation 10), the only source term is the in-situ production because the particles introduced in the water column of the margin do not contain ${ }^{230} \mathrm{Th}_{\mathrm{xs}}$ (hypothesis 3). The relationship between $C_{d}$ and $C_{p}$ is obtained by assuming a reversible equilibrium between dissolved and particulate Th:

$C_{p}^{i}=K \times m^{i} \times C_{d}^{i}$

$C_{p}^{m}=K \times m^{m} \times C_{d}^{m}$ 
632 (mass of radionuclide carried by particles per $L$ of seawater) and the dissolved fraction (mass 633 of radionuclide in solution per $L$ of seawater) ( $K=$ concentration in particles/concentration in 634 the dissolved phase). $K$ is assumed to be constant with depth and particle concentration. 635 Assuming a steady state, we obtain:

$\frac{d\left(m^{m} C_{d}^{m}\right)}{d z}=\frac{1}{s^{m}}\left\{k_{m}\left(\left(1+K \times m^{i}\right) C_{d}^{i}-\left(1+K \times m^{m}\right) C_{d}^{m}\right)+P_{230}\right\}$

$\frac{d\left(m^{i} C_{d}^{i}\right)}{d z}=\frac{1}{s^{i}}\left\{k_{i}\left(\left(1+K \times m^{m}\right) C_{d}^{m}-\left(1+K \times m^{i}\right) C_{d}^{i}\right)+P_{230}\right\}$ already obtained for modelling the boundary scavenging in the Arctic Ocean (Roy-Barman, 2009). The water residence time with respect to horizontal exchange is $10 \mathrm{y}$ for the ocean margin and $50 \mathrm{y}$ for the ocean interior (Tab. 1). All the other parameter are adjusted by trial and error in order to obtain a reasonable agreement (Fig. 7) with the dissolved and particulate profiles of station 32 (Nansen margin) and station 50 (Nansen interior, above $2000 \mathrm{~m}$ to avoid the hydrothermal scavenging that is not represented in the model). Qualitatively equivalent results were obtained for station 32 and station 101 (not shown). The boundary conditions for the particle concentration are $m^{m}(0)=1$ (by definition of $m$ ) and $m^{i}(0)=1.5$ to obtain a reasonable fit between the model and the ${ }^{230} \mathrm{Th}$ profile (see discussion below). This implies that there is an input of particles in the surface waters at the margin and in the interior ocean. We use $\mu=0.5 \mathrm{y}^{-1}$. As the particle settling speed at the margin is set a $600 \mathrm{~m} / \mathrm{y}$, it corresponds to an increase of the particle concentration at the margin of a factor 2.71 every $1200 \mathrm{~m}$ of depth. By default, we choose the same value for $K(=0.11)$, at the margin and in the inner ocean. If we want to reproduce the similar vertical ${ }^{230} \mathrm{Th}_{p}$ gradients observed at the margin and in the inner ocean (Fig. 3), the settling velocity of the particles must be higher at the margin $(600 \mathrm{~m} / \mathrm{y})$ compared to the ocean interior $\left(340 \mathrm{~m} / \mathrm{y}\right.$. Indeed, if $\frac{d C_{p}^{m}}{d z} \approx \frac{d C_{p}^{i}}{d z}$, equations 14 and 15 can be combined to yield: inner ocean must be removed by settling particles with the same vertical ${ }^{230} \mathrm{Th}_{\mathrm{p}}$ gradient as in 
particles with the same vertical ${ }^{230} \mathrm{Th}_{p}$ gradient as at the margin. Note that $S^{i}=S^{m}$, only if $k_{i}=$ $k_{m}=0$. This corresponds to the $1 \mathrm{D}$ reversible scavenging model that would not account for the increasing ${ }^{230} \mathrm{Th}$ particulate fraction with depth and for the non-linear dissolved ${ }^{230} \mathrm{Th}$ profiles.

Given the simplicity of the model, we do not expect a full agreement with the data despite some tuning of the parameters. For example, the hydrothermal scavenging of ${ }^{230} \mathrm{Th}_{\mathrm{xs}}$ below $2000 \mathrm{~m}$ depth, possibly occurring at station 50 is not represented in the model. Nevertheless, we believe that the model captures some effects of particle accumulation and scavenging at depth. This is in line with 3D modelling results showing that dissolved Th and Pa profiles in the Atlantic Ocean are better simulated when a parametrization of boundary and bottom scavenging is introduced (Rempfer et al., 2017).

As observed in the data, the modelled dissolved ${ }^{230} \mathrm{Th}_{\mathrm{xs}}$ concentration profiles increase with depth followed by a decrease in concentration approaching the seafloor (Fig. 7). The model also captures the linear increase of the particulate ${ }^{230} \mathrm{Th}_{\mathrm{xs}}$ concentrations with depth, as observed in the data (Fig. 7). Despite the reversible scavenging equilibrium hypothesis, dissolved and particulate ${ }^{230} \mathrm{Th}_{\mathrm{xs}}$ are not proportional because the mass of particles " $m$ " increases with depth (eq. 1). Therefore, the linear particulate ${ }^{230} \mathrm{Th}_{\mathrm{xs}}$ profiles result from the gross linear increase of the ${ }^{230} \mathrm{Th}_{\mathrm{xs}}$ in-situ production with depth (it is not perfectly linear due to lateral transport). Despite this linear increase of the particulate ${ }^{230} \mathrm{Th}_{\mathrm{xs}}$, the dissolved ${ }^{230} \mathrm{Th}_{\mathrm{xs}}$ concentrations can decrease with depth due to the increased particulate scavenging. As a consequence of the dissolved and particulate profile shapes, the particulate/total fraction of ${ }^{230} \mathrm{Th}_{\mathrm{xs}}$ increases with depth as observed in the data (Fig. 5 and 7).

The measured particulate ${ }^{230} \mathrm{Th}_{\mathrm{xs}}$ concentrations are relatively similar at stations 32 , 50 and 101 (Fig. 3). This is surprising and probably circumstantial: the high particle mass equilibrating with a low dissolved ${ }^{230} \mathrm{Th}_{\mathrm{xs}}$ content at the margin balances the lower mass of particles equilibrating with a higher dissolved ${ }^{230} \mathrm{Th}_{\mathrm{xs}}$ concentration at the interior ocean. $\mathrm{A}$ direct consequence of these similar particulate ${ }^{230} \mathrm{Th}_{\mathrm{xs}}$ profiles is that the vertical flux of ${ }^{230} \mathrm{Th}_{\mathrm{xs}}$ is increased at the margin where the particle settling velocity is higher compared to the ocean interior. Hence, boundary scavenging occurs. fraction compared to the ${ }^{230} \mathrm{Th}_{\mathrm{xs}}$ particulate fraction (Fig. 5). As a consequence, ${ }^{231} \mathrm{~Pa}_{\mathrm{xs}}$ profiles generally deviate more strongly from the linear increase expected from reversible scavenging due to a significant transport by advection (e.g. Hayes et al., 2015; Gdaniec et al., 2017). In the Arctic, Moran et al. (2005) estimated that $39 \%$ of the ${ }^{231} \mathrm{~Pa}_{\mathrm{xs}}$ produced in the Arctic Ocean is expected to be exported to the Atlantic Ocean through the Fram Strait. However, in the 
Makarov Basin, ventilation cannot account for the non-linear ${ }^{231} \mathrm{~Pa}$ profile, as the residence time of the deep water is several hundreds of years (e.g. Rutgers van der Loeff et al., 2018). Therefore, this non-linear profile may be related to scavenging along the basin boundaries (Roy-Barman, 2009).

On the Barents Shelf (St. 153 and 161), representing the inflow of unmodified Atlantic waters, the dissolved ${ }^{231} \mathrm{~Pa}_{\mathrm{xs}}$ is in the same range as the concentrations $\left({ }^{231} \mathrm{~Pa}_{\mathrm{xs}}=0.33-0.68\right.$ $\mathrm{fg} / \mathrm{kg}$ ) measured in the northeastern Atlantic (Hayes et al., 2015). At stations 04 and 18, the dissolved ${ }^{231} \mathrm{~Pa}_{\mathrm{xs}}(0.19-0.36 \mathrm{fg} / \mathrm{kg})$ becomes slightly lower, possibly reflecting scavenging of ${ }^{231} \mathrm{~Pa}_{\mathrm{xs}}$ on the Barents Shelf (Fig. 2). Pa scavenging over the Barents Self is not surprising because the area is known for its diatom blooms (Wassmann et al., 1990). The dissolved ${ }^{231} \mathrm{~Pa}_{\mathrm{xs}}$ in shallow waters $(<500 \mathrm{~m})$ over the slope (St. 32) and the Nansen Basin (stations 40 and 50$)\left({ }^{231} \mathrm{~Pa}_{\mathrm{xs}}=0.20-0.4 \mathrm{fg} / \mathrm{kg}\right)$ are intermediate between the Atlantic inflowing water (stations 153 and 161) and close to Svalbard (St. 4).

As for the ${ }^{230} \mathrm{Th}_{\mathrm{xs}}$ (and ${ }^{232} \mathrm{Th}$ ) in bottom waters of station 153 and 161, depleted concentrations of dissolved ${ }^{231} \mathrm{~Pa}_{\mathrm{xs}}$ were accompanied with elevated particulate ${ }^{231} \mathrm{~Pa}_{\mathrm{xs}}$ concentrations (Fig. 2 and 3), indicating removal of ${ }^{231} \mathrm{~Pa}_{\mathrm{xs}}$ at the Barents shelf, close to the seafloor. The particulate fraction of ${ }^{231} \mathrm{~Pa}_{\mathrm{xs}}$ in deep waters of the interior Nansen was very small (0.2-0.9\%) compared to ${ }^{230} \mathrm{Th}_{\mathrm{xs}}(25-48 \%)$, which is expected due to the overall lower particle reactivity of ${ }^{231} \mathrm{~Pa}$ (compared to ${ }^{230} \mathrm{Th}$ ).

Extremely low dissolved ${ }^{231} \mathrm{~Pa}_{\mathrm{xs}}$ concentrations $(0.02 \pm 0.005 \mathrm{fg} / \mathrm{kg})$ were observed in surface waters $\left(10-100 \mathrm{~m}\right.$ ) of station 101 (Fig. 2). As the high ${ }^{232} \mathrm{Th}$ content of these waters was attributed to advection by the transpolar drift (e.g. Rutgers van der Loeff et al., 2018), it is likely that these waters were completely depleted of their ${ }^{231} \mathrm{~Pa}$ over the shelf and that during their transit to station 101 reversible scavenging has acted to build up a linear equilibrium profile. The sea-ice cover has prevented this equilibrium profile $(>100 \mathrm{~m})$ from rehomogenization by wind-induced mixing.

In the deep basins, deep/bottom scavenging also occurs, as suggested by the elevated particulate ${ }^{231} \mathrm{~Pa}_{\mathrm{xs}}$ concentrations below $2000 \mathrm{~m}$ depth observed at station 32 and 50 that indicate removal of ${ }^{231} \mathrm{~Pa}_{\mathrm{xs}}$ in deep waters of the Nansen Basin (Fig. 3). However, in contrast to ${ }^{230} \mathrm{Th}_{\mathrm{xs}}$, higher ${ }^{231} \mathrm{~Pa}_{\mathrm{xs}}$ particulate fractions were observed at station 50 relative to station 32 (Fig. 5), suggesting the presence at station 50 of hydrothermal particles which are known to have a high affinity for $\mathrm{Pa}$.

Unlike dissolved ${ }^{230} \mathrm{Th}_{\mathrm{xs}}$ profiles, the dissolved ${ }^{231} \mathrm{~Pa}_{\mathrm{xs}}$ profiles in the Nansen and Amundsen Basin have similar shapes probably due to the much longer scavenging residence time of $\mathrm{Pa}$ relative to Th. By contrast, ${ }^{231} \mathrm{~Pa}_{\mathrm{xs}}$ concentrations are higher in the intermediate/deep Makarov Basin (St. 101) than in the Eurasian Basin due to the long term isolation of these 2 basins by the Lomonosov ridge (Fig. 2). Interestingly, there are two distinct correlations 
between dissolved silica (DSi) and dissolved ${ }^{231} \mathrm{~Pa}_{\mathrm{xs}}$ in the deep waters of the Nansen and the Makarov Basins (Fig. 8). These positive correlations are likely due to the high affinity of ${ }^{231} \mathrm{~Pa}$ for biogenic silica (BSi) (e.g. Chase et al., 2002). We propose that ${ }^{231} \mathrm{~Pa}$ is scavenged by BSi formed in surface waters. As these particles settle through the water column, BSi dissolves and releases ${ }^{231} \mathrm{~Pa}$ into solution again. The steeper slope of the dissolved ${ }^{231} \mathrm{~Pa} \mathrm{a}_{\mathrm{xs}}$ versus DSi correlation in the Makarov Basin compared to the Nansen Basin is likely due to accumulation of in-situ produced ${ }^{231} \mathrm{~Pa}$ (in addition to the BSi dissolution effect) during the longer aging of the deep Makarov/Canadian waters.

\subsection{Applying the boundary scavenging model to $\mathrm{Pa}$}

The boundary scavenging model developed for ${ }^{230} \mathrm{Th}$ is now applied to ${ }^{231} \mathrm{~Pa}$ with the appropriate changes (Tab. 1). The production rate is changed $(0.025 \mathrm{fg} / \mathrm{kg} / \mathrm{y})$ and the dissolved-particulate partition coefficient is divided by 12 because we have estimated that $\mathrm{F}_{\mathrm{Th} / \mathrm{Pa}} \sim 12$ (Fig. 4). Several similarities and differences arise between the model and measured data.

The model reproduces the non-linear shape of the dissolved ${ }^{231} \mathrm{~Pa}_{\mathrm{xs}}$ profiles (particularly at St. 50) and the relatively linear particulate ${ }^{231} \mathrm{~Pa}_{\mathrm{xs}}$ profiles of station 32 and 50. However, the modelled dissolved ${ }^{231} \mathrm{~Pa}_{\mathrm{xs}}$ concentrations are overestimated by a factor 2 to 4 (Fig. 7). Modelled particulate ${ }^{231} \mathrm{~Pa}_{\mathrm{xs}}$ concentrations at the margin are also overestimated. The reason for the overestimated dissolved ${ }^{231} \mathrm{~Pa}_{\mathrm{xs}}$ concentrations is probably a mix of previously discussed processes and because of the possible underestimation of the particulate $\mathrm{Pa}$ concentration revealed by intercomparison work at station 101 (higher particulate $\mathrm{Pa}$ concentration would result in a higher removal rate by scavenging on setting particles). Scavenging of ${ }^{231} \mathrm{~Pa}_{\mathrm{xs}}$ by hydrothermal plumes can severely deplete the concentrations of ${ }^{231} \mathrm{~Pa}_{\mathrm{xs}}$ in the deep Arctic Ocean (Valk et al., 2018). Export of ${ }^{231} \mathrm{~Pa}$ through advection has been proposed to have a significant importance in several studies (e.g. Hoffmann et al., 2013; Moran et al., 2005). The dissolved ${ }^{231} \mathrm{~Pa}$ concentrations of the deep inflow through the Fram Strait Branch ( $\left.{ }^{231} \mathrm{~Pa} \sim 1-1.5 \mathrm{fg} / \mathrm{kg}\right)$ agrees well with the value $\left({ }^{231} \mathrm{~Pa}=1.5 \mathrm{fg} / \mathrm{kg}\right)$ used in Moran et al. (2005). The ${ }^{231} \mathrm{~Pa}$ concentrations reported here for the return in the Nansen Basin at station $50\left({ }^{231} \mathrm{~Pa} \sim 1-1.5 \mathrm{fg} / \mathrm{kg}\right)$ is close to the Fram Strait Branch. By contrast, in the deep Makarov Basin, above the sill on the Lomonosov ridge is $\left({ }^{231} \mathrm{~Pa} \sim 1.5-3.0 \mathrm{fg} / \mathrm{kg}\right)$ consistent with Moran et al (2005) estimates. This ${ }^{231} \mathrm{~Pa}$ gradient between the inflow and outflow supports a net export of ${ }^{231} \mathrm{~Pa}$ into the Atlantic.

Finally, boundary scavenging along the slopes of the Eurasian Basin can reduce the dissolved ${ }^{231} \mathrm{~Pa}$ in the deep Arctic Ocean. Probably, ${ }^{231} \mathrm{~Pa} /{ }^{230} \mathrm{Th}$ ratios of the suspended 
sediments of the Nansen margin and slope have high ${ }^{231} \mathrm{~Pa} /{ }^{230} \mathrm{Th}$-ratios, suggesting that the Nansen margin is in fact a large sink for ${ }^{231} \mathrm{~Pa}$ in the Arctic Ocean.

Roy-Barman (2009) proposed a balanced Arctic budget of ${ }^{231} \mathrm{~Pa}$ between the inner ocean and the margin without export of ${ }^{231} \mathrm{~Pa}$ through the Fram Strait. However, it was based on very low $\mathrm{F}_{\mathrm{Th} / \mathrm{Pa}}$ values ( 3-10) compared to the values reported in the present work.

\subsection{Factors controlling $\mathrm{Pa}-\mathrm{Th}$ fractionation}

\subsubsection{The Th-Pa fractionation factor}

${ }^{231} \mathrm{~Pa}_{\mathrm{xs}}$ is generally less particle reactive than ${ }^{230} \mathrm{Th}_{\mathrm{xs}}$, which results in ${ }^{231} \mathrm{~Pa}_{\mathrm{xs}}$ profiles that deviate more strongly from the linear increase expected from reversible scavenging due to transport by advection (e.g. Chase et al., 2002; Hayes et al., 2015; Gdaniec et al., 2017). The particulate content of ${ }^{231} \mathrm{~Pa}_{\mathrm{xs}}$ relative to the total ${ }^{231} \mathrm{~Pa}_{\mathrm{xs}}$ concentrations was in the order of 0.6 $-1 \%$ in the deep stations (<2000 $\mathrm{m}$ ) and up to $15 \%$ on the shelf, while particulate/total ratios for ${ }^{230} \mathrm{Th}_{\mathrm{xs}}$ ranged between $6 \%$ and $17 \%$ in the deep stations and up to $80 \%$ on the shelf (Fig. 5). This reflects the preferential scavenging of ${ }^{230} \mathrm{Th}_{\mathrm{xs}}$ relative to ${ }^{231} \mathrm{~Pa}_{\mathrm{xs}}$, As a consequence, the $\mathrm{F}_{\mathrm{Th} / \mathrm{Pa}}$ in the open ocean is typically around 20 (e.g. Hayes et al., 2015b), mostly when carbonate, organic and lithogenic particles dominates. Notable exceptions are environments where particulate matter is dominated by diatoms $\left(F_{T h / P a}<5\right.$, e.g. Scholten et al., 2008; Venchiarutti et al., 2011a; Venchiarutti et al., 2011b) or Mn-Fe (oxy)hydroxides, such as in hydrothermal plumes $\left(\mathrm{F}_{\mathrm{Th} / \mathrm{Pa}}=6 \pm 3\right.$ for $\mathrm{MnO}_{2}$ and $\mathrm{F}_{\mathrm{Th} / \mathrm{Pa}}=11 \pm 6$ for $\mathrm{Fe}(\mathrm{OH})_{3}$, Hayes et al., 2015; Pavia et al., 2018). As a consequence of these different drivers, 2 types of $F_{T h / P a}$ depth profiles are generally observed:

1) In the North Atlantic $F_{T h / P a}$ decreases with depth because the particulate matter composition evolves from lithogenic/carbonated in the surface water to strongly affected by Fe-Mn oxides due to hydrothermal particles above and around the Mid-Atlantic Ridge or to oxidation/precipitation of Fe-Mn released in the oxygen minimum zone off the Mauritanian coast.

2) In areas dominated by diatom production, $F_{T h / P a}$ tends to increase with depth as a consequence of the biogenic silica dissolution (Scholten et al., 2008; Venchiarutti et al., 2011), because opal tends to dissolve during the settling through the water column (Nelson et al., 1995). In the Arctic, this view is supported by the strong correlation observed between dissolved ${ }^{231} \mathrm{~Pa}$ and dissolved Si of the deep Makarov and Nansen Basins (Fig 8).

The $\mathrm{F}_{\mathrm{Th} / \mathrm{Pa}}$ profiles that we obtained on the Nansen margin (St. 32, 153 and 161) and in the Makarov Basin (St. 101) show a clear increase with depth (from $\mathrm{F}_{\mathrm{Th} / \mathrm{Pa}} \approx 2-5$ in the shallow waters to $\mathrm{F}_{\mathrm{Th} / \mathrm{Pa}} \approx 20$ in the deep waters) suggesting surface particles dominated by diatoms and deeper particles with an increasing influence of lithogenic particles resuspended and advected from the margin. At station 50, the limited increase of $\mathrm{F}_{\mathrm{Th} / \mathrm{Pa}}$ below $2000 \mathrm{~m}\left(\mathrm{~F}_{\mathrm{Th} / \mathrm{Pa}} \approx\right.$ 
10) supports that particles at this station still include some particles derived from the hydrothermal activity, even if at the time of sampling most of the plume itself had left the Gakkel ridge and cannot be clearly detected with beam transmission data (Valk et al., 2018).

\subsubsection{Large scale Pa-Th fractionation}

811 Early studies of $\mathrm{Pa}$-Th in the Arctic Ocean have emphasized that despite of the large shelf 812 areas, the large Pa-Th fractionation observed in the Pacific Ocean sediments between the 813 ocean margin $\left(\left[{ }^{231} \mathrm{~Pa}_{\mathrm{xs}}{ }^{230} \mathrm{Th}_{\mathrm{xs}}\right] \approx 3\right.$ * production ratio) and the ocean interior $\left(\left[{ }^{231} \mathrm{~Pa}_{\mathrm{xs}} /{ }^{230} \mathrm{Th}_{\mathrm{xs}}\right] \approx\right.$ $8140.3^{*}$ production ratio) was not present in Arctic Ocean sediments. Instead, most Arctic 815 sediments have $\left[{ }^{231} \mathrm{~Pa}_{\mathrm{xs}} / 230 \mathrm{Th}_{\mathrm{xs}}\right]$ activity ratios significantly lower than the production ratio 816 (Edmonds et al., 2004; Moran et al., 2005). Recently, a few sediment samples collected on the 817 Siberian shelf margins were reported to have ${ }^{231} \mathrm{~Pa}_{\mathrm{xs}} / 230 \mathrm{Th}_{\mathrm{xs}}$ ratios that slightly exceed the 818 production ratio (Luo and Lippold, 2015). Moreover, Hoffmann et al. (2013) observed decreasing Arctic sedimentary ${ }^{231} \mathrm{~Pa} /{ }^{230} \mathrm{Th}$ ratios with water depth, over the last $30 \mathrm{kyr}$. This general deficit in ${ }^{231} \mathrm{~Pa}_{\mathrm{xs}}$ was attributed to the export of a significant fraction of the Arctic ${ }^{231} \mathrm{~Pa}_{\mathrm{xs}}$ into the Atlantic Ocean through the Fram Strait and to the hypothetical possibility that some of the ${ }^{231} \mathrm{~Pa}_{\mathrm{xs}}$ was lost by boundary scavenging in a location not identified at that time.

The data obtained in this work on the suspended particles of the Nansen margin (St. 32, 158 and 161) show particulate $\left[{ }^{231} \mathrm{~Pa}_{\mathrm{xs}} /{ }^{230} \mathrm{Th}_{\mathrm{xs}}\right]$ activity ratios below the production ratio except in the surface waters, but the calculation of the particulate ${ }^{231} \mathrm{~Pa}_{\mathrm{xs}}$ is affected by large uncertainties (Tab. ES2). However, Top-core sediments from the Nansen margin (St. 161 and 32) have distinctly high $\left[{ }^{231} \mathrm{~Pa}_{\mathrm{xs}} /{ }^{230} \mathrm{Th}_{\mathrm{xs}}\right]$ activity ratios: $\left[{ }^{231} \mathrm{~Pa}_{\mathrm{xs}}{ }^{230} \mathrm{Th}_{\mathrm{xs}}\right]=0.40$ at station 161 and 0.18 at station 32 (Tab S3). Hence, the $\left[{ }^{231} \mathrm{~Pa}_{\mathrm{xs}} /{ }^{230} \mathrm{Th}_{\mathrm{xs}}\right]$ activity ratios of these two surface sediment samples are much higher than the corresponding ratio in the suspended particles. These ratios at station 161 and 32 are well above the values reported by Moran et al. (2005). So boundary scavenging along the Nansen margin could contribute to the ${ }^{231} \mathrm{~Pa}$ depletion in the Arctic Ocean. Scavenging by the hydrothermal plume turns out to be an alternative sink. Moreover, the discrepancies between the sediment and particulate ${ }^{231} \mathrm{~Pa} /{ }^{230} \mathrm{Th}$ ratios might be related to the different timescales of these data records. Still, particulate samples in the deep part of the station 50 have ${ }^{231} \mathrm{~Pa}_{\mathrm{xs}} /{ }^{230} \mathrm{Th}_{\mathrm{xs}}$ ratios below the production ratio despite the

836 relatively low $\mathrm{F}_{\mathrm{Th} / \mathrm{Pa}}$ (Tab. ES2). Whether these particles are still dominated by hydrothermal particles or not remains ambiguous (Valk et al., 2018). 


\section{Conclusions}

839 The distribution of ${ }^{231} \mathrm{~Pa}_{\mathrm{xs}}$ and ${ }^{230} \mathrm{Th}_{\mathrm{xs}}$ in the Arctic Ocean deviates from the linear increase 840 expected from reversible scavenging in absence of lateral advection. While the role of 841 hydrothermal scavenging of ${ }^{230}$ Th recently has been highlighted in the Nansen Basin (Valk et

842 al., 2018), we show here that boundary scavenging also removes significant amounts of ${ }^{230} \mathrm{Th}$ 843 at the Nansen margin.

844 Scavenging on particles derived from hydrothermal activity is associated with a 845 relatively low $\mathrm{F}_{\mathrm{Th} / \mathrm{Pa}}$ fractionation factor $(\approx 10)$, while higher $\mathrm{F}_{\mathrm{Th} / \mathrm{Pa}}(\approx 20)$ were observed for deep 846 and bottom waters both of the Eurasian and Makarov Basin.

The modified boundary scavenging model developed here for the Nansen Basin, successfully modeled the increasing ${ }^{230} \mathrm{Th}_{\mathrm{xs}}$ particulate fraction with depth and the decrease of dissolved Pa-Th contents approaching the seafloor observed on various margins. Modeled dissolved ${ }^{231} \mathrm{~Pa}$ distributions were largely overestimated. These results suggest that advection of dissolved ${ }^{231} \mathrm{~Pa}$ out the Atlantic is an important sink for the Arctic ${ }^{231} \mathrm{~Pa}$ budget. However, the high sedimentary ${ }^{231} \mathrm{~Pa}_{\mathrm{xs}} /{ }^{230} \mathrm{Th}_{\mathrm{xs}}$ ratios observed at the Barents Sea shelf and Nansen margin indicate that the Arctic margins could indeed act as a major sink for the missing Arctic ${ }^{231} \mathrm{~Pa}$. More data focused on shelves and slopes of the Arctic Ocean are required to better constrain this effect and the chemical nature of the particles and their physical mode of resuspension have to be addressed more precisely.

\section{Acknowledgements}

This work was conducted in the framework of the GEOTRACES program and was supported by the Swedish Research Council (VR 349-202-6287). The authors are pleased to thank the captains and the crew of the research vessel R/V Polarstern. Ronja Paffrath is thanked for the sampling of seawater. Karin Wallner is acknowledged for their critical roles in the laboratory work. Aridane G. González is acknowledged for melting ice rafted sediments samples. Lise Missiaen was supported by an ERC funding to the ACCLIMATE project. The constructive comments of 2 anonymous reviewers greatly improved the present manuscript.

\section{References}

Aagaard, K., Britain, G., Aagaard, K., Carmack, E., 1981. On the halocline of the Arctic Ocean. Deep. Res. 28, 529-545. 
Bacon, M.P., Anderson, R.F., 1982. Distribution of Thorium isotopes between dissolved and particulate forms in the deep sea. J. Geophys. Res. 87, 2045-2056. https://doi.org/10.1029/JC087iC03p02045

Bacon, M.P., Huh, C.A., Moore, R.M., 1989. Vertical profiles of some natural radionuclides over the Alpha Ridge, Arctic Ocean. Earth Planet. Sci. Lett. 95, 15-22. https://doi.org/10.1016/0012-821X(89)90164-7

Björk, G., Anderson, L.G., Jakobsson, M., Antony, D., Eriksson, P.B., Hell, B., Hjalmarsson, S., Janzen, T., Jutterstr, S., Marcussen, C., Olsson, K.A., Rudels, B., Linders, J., Ludvig, L., Sølvsten, M., Selle, E., 2010. Deep-Sea Research I Flow of Canadian basin deep water in the Western Eurasian Basin of the Arctic Ocean 57, 577-586. https://doi.org/10.1016/j.dsr.2010.01.006

Björk, G., Jakobsson, M., Rudels, B., Swift, J.H., Anderson, L., Darby, D.A., Backman, J., Coakley, B., Winsor, P., Polyak, L., Edwards, M., 2007. Bathymetry and deep-water exchange across the central Lomonosov Ridge at $88-89^{\circ}$ N. Deep. Res. Part I Oceanogr. Res. Pap. 54, 1197-1208. https://doi.org/10.1016/j.dsr.2007.05.010

Chase, Z., Anderson, R.F., Fleisher, M.Q., Kubik, P.W., 2002. The influence of particle composition and particle flux on scavenging of $\mathrm{Th}, \mathrm{Pa}$ and $\mathrm{Be}$ in the ocean. Earth Planet. Sci. Lett. 204, 215-229. https://doi.org/10.1016/S0012-821X(02)00984-6

Cheng, H., Edwards, R.L., Murrell, M.T., Benjamin, T.M., 1998. Uranium-thoriumprotactinium dating systematics. Geochim. Cosmochim. Acta 62, 3437-3452. https://doi.org/http://dx.doi.org/10.1016/S0016-7037(98)00255-5

Cochran, J.K., Hirschberg, D.J., Livingston, H.D., Buesseler, K.O., Key, R.M., 1995. Natural and anthropogenic radionuclide distributions in the Nansen Basin, Artic Ocean: Scavenging rates and circulation timescales. Deep. Res. Part II 42, 1495-1517. https://doi.org/10.1016/0967-0645(95)00051-8

Condon, D.J., McLean, N., Noble, S.R., Bowring, S.A., 2010. Isotopic composition $(238 \mathrm{U} / 235 \mathrm{U})$ of some commonly used uranium reference materials. Geochim. Cosmochim. Acta 74, 7127-7143. https://doi.org/10.1016/j.gca.2010.09.019

Edmonds, H.N., 1998. Protactinium-231 and Thorium-230 Abundances and High Scavenging Rates in the Western Arctic Ocean. Science (80-. ). 280, 405-407. https://doi.org/10.1126/science.280.5362.405

Edmonds, H.N., Moran, S.B., Cheng, H., Edwards, R.L., 2004. 230Th and 231Pa in the Arctic Ocean: Implications for particle fluxes and basin-scale $\mathrm{Th} / \mathrm{Pa}$ fractionation. Earth Planet. Sci. Lett. 227, 155-167. https://doi.org/10.1016/j.epsl.2004.08.008

Gdaniec, S., Roy-Barman, M., Foliot, L., Thil, F., Dapoigny, A., Burckel, P., Garcia-Orellana, J., Masqué, P., Mörth, C.-M., Andersson, P.S., 2017. Thorium and protactinium isotopes as tracers of marine particle fluxes and deep water circulation in the Mediterranean Sea. Mar. Chem. 199, 12-23. https://doi.org/10.1016/j.marchem.2017.12.002

Guihou, A., Pichat, S., Nave, S., Govin, A., Labeyrie, L., Michel, E., Waelbroeck, C., 2010. 
Late slowdown of the Atlantic Meridional Overturning Circulation during the Last Glacial Inception: New constraints from sedimentary (231Pa/230Th). Earth Planet. Sci. Lett. 289, 520-529. https://doi.org/10.1016/j.epsl.2009.11.045

Hayes, C.T., Anderson, R.F., Fleisher, M.Q., Huang, K.F., Robinson, L.F., Lu, Y., Cheng, H., Edwards, R.L., Moran, S.B., 2015a. ${ }^{230}$ Th and ${ }^{231} \mathrm{~Pa}$ on GEOTRACES GA03, the U.S. GEOTRACES North Atlantic transect, and implications for modern and paleoceanographic chemical fluxes. Deep. Res. Part II Top. Stud. Oceanogr. 116, 2941. https://doi.org/10.1016/j.dsr2.2014.07.007

Hayes, C.T., Anderson, R.F., Fleisher, M.Q., Vivancos, S.M., Lam, P.J., Ohnemus, D.C., Huang, K.F., Robinson, L.F., Lu, Y., Cheng, H., Edwards, R.L., Moran, S.B., 2015b. Intensity of Th and $\mathrm{Pa}$ scavenging partitioned by particle chemistry in the North Atlantic Ocean. Mar. Chem. 170, 49-60. https://doi.org/10.1016/j.marchem.2015.01.006

Hillaire-Marcel, C., McManus, J., Ghaleb, B., Vernal, A. de, Maccali, J., Cuny, K., Jacobel, A., C. Le Duc, 2017. A New Chronology of Late Quaternary Sequences From the Central Arctic Ocean Based on "'Extinction Ages"' of Their Excesses in 231Pa and 230Th 4573-4585. https://doi.org/10.1002/2017GC007050

Hoffmann, S.S., McManus, J.F., Curry, W.B., Susan Brown-Leger, L., 2013. Persistent export of $231 \mathrm{~Pa}$ from the deep central Arctic Ocean over the past 35,000 years. Nature 497, 603-606. https://doi.org/10.1038/nature12145

Huh, C.A., Pisias, N.G., Kelley, J.M., Maiti, T.C., Grantz, A., 1997. Natural radionuclides and plutonium in sediments from the western Arctic Ocean: Sedimentation rates and pathways of radionuclides. Deep. Res. Part II Top. Stud. Oceanogr. 44, 1725-1743. https://doi.org/10.1016/S0967-0645(97)00040-4

Ivanova, E. V, Murdmaa, I.O., Duplessy, J., Paterne, M., 2002. Late Weichselian to Holocene paleoenvironments in the Barents Sea. Glob. Planet. Change 34, 209-218.

Jakobsson, M., 2002. Hypsometry and volume of the Arctic Ocean and its constituent seas. Geochemistry, Geophys. Geosystems 3, 1-18. https://doi.org/10.1029/2004GC000694

Lukashin, V.N., Shcherbinin, A.D., 2007. Hydrological Properties, Suspended Matter, and Particulate Fluxes in the Water Column of the Bear Island Trough. Mar. Geol. 47, 6879. https://doi.org/10.1134/S0001437007010109

Luo, Y., Lippold, J., 2015. Controls on ${ }^{231} \mathrm{~Pa}$ and ${ }^{230}$ Th in the Arctic Ocean. Geophys. Res. Lett. n/a-n/a. https://doi.org/10.1002/2015GL064671

Moran, S.B., Hoff, J.A., Buesseler, K.O., Edwards, R.L., 1995. High precision 230Th and 232Th in the Norwegian Sea and Denmark by thermal ionization mass spectrometry. Geophys. Res. Lett. 22, 2589-2592.

Moran, S.B., Shen, C.C., Edmonds, H.N., Weinstein, S.E., Smith, J.N., Edwards, R.L., 2002. Dissolved and particulate 231Pa and 230Th in the Atlantic Ocean: Constraints on intermediate/deep water age, boundary scavenging, and 231Pa/230Th fractionation. Earth Planet. Sci. Lett. 203, 999-1014. https://doi.org/10.1016/S0012-821X(02)00928-7 
Moran, S.B., Shen, C.C., Edwards, R.L., Edmonds, H.N., Scholten, J.C., Smith, J.N., Ku, T.L., 2005. 231Pa and 230Th in surface sediments of the Arctic Ocean: Implications for $231 \mathrm{~Pa} / 230 \mathrm{Th}$ fractionation, boundary scavenging, and advective export. Earth Planet. Sci. Lett. 234, 235-248. https://doi.org/10.1016/j.epsl.2005.02.016

Moran, S.B., Shen, C.C., Weinstein, S.E., Hettinger, L.H., Hoff, J.H., Edmonds, H.N., Edwards, R.L., 2001. Constraints on deep water age and particle flux in the Equatorial and South Atlantic Ocean based on seawater 231Pa and 230Th data. Geophys. Res. Lett. 28, 3437-3440. https://doi.org/10.1029/2001GL013339

Nelson, D.M., Tréguer, P., Brzezinski, M.A., Leynaert, A., Quéguiner, B., 1995. Production and dissolution of biogenic silica in the ocean: Revised global estimates, comparison with regional data and relationship to biogenic sedimentation. Global Biogeochem. Cycles 9, 359-372. https://doi.org/10.1029/95GB01070

Not, C., Brown, K., Ghaleb, B., Hillaire-Marcel, C., 2012. Conservative behavior of uranium vs. salinity in Arctic sea ice and brine. Mar. Chem. 130-131, 33-39. https://doi.org/10.1016/j.marchem.2011.12.005

Nowaczyk, N.R., Frederichs, T.W., Kassens, H., Norgaard-pedersen, N., Spielhagen, R.F., Stein, R., Weiel, D., 2001. Sedimentation rates in the Makarov Basin, central Arctic Ocean: A paleomagnetic and rock magnetic approach. Paleoceanography 16, 368-389.

Okubo, A., Takeda, S., Obata, H., 2013. Atmospheric deposition of trace metals to the western North Paci fi c Ocean observed at coastal station in Japan. Atmos. Res. 129130, 20-32. https://doi.org/10.1016/j.atmosres.2013.03.014

Owens, S.A., Buesseler, K.O., Sims, K.W.W., 2011. Re-evaluating the 238U-salinity relationship in seawater: Implications for the 238U-234Th disequilibrium method. Mar. Chem. 127, 31-39. https://doi.org/10.1016/j.marchem.2011.07.005

Pavia, F., Anderson, R., Vivancos, S., Fleisher, M., Lam, P., Lu, Y., Cheng, H., Zhang, P., Lawrence Edwards, R., 2018. Intense hydrothermal scavenging of 230Th and 231Pa in the deep Southeast Pacific. Mar. Chem. 201, 212-228. https://doi.org/10.1016/j.marchem.2017.08.003

Pfirman, S., Thiede, J., 1987. Lithogenic sediment on Arctic pack ice: Potential aeolian flux and contribution to deep sea sediments, in: Paleoclimatology and Paleometeorology: Modern and Past Patterns of Global Atmospheric Transport. pp. 463-493.

Rijkenberg, M.J.A., Slagter, H.A., Rutgers van der Loeff, M., van Ooijen, J., Gerringa, L.J.A., 2018. Dissolved Fe in the Deep and Upper Arctic Ocean With a Focus on Fe Limitation in the Nansen Basin. Front. Mar. Sci. 5, 1-14. https://doi.org/10.3389/fmars.2018.00088

Roy-Barman, M., 2009. Modelling the effect of boundary scavenging on Thorium and Protactinium profiles in the ocean. Biogeosciences 6, 7853-7896. https://doi.org/10.5194/bgd-6-7853-2009

Rudels, B., 2009. Arctic ocean circulation. Finnish Institute of Marine Research, Helsinki, Finland, pp. 211-225. 
1002

1003

1004

1005

1006

1007

1008

1009

1010

1011

1012

1013

1014

1015

1016

1017

1018

1019

Rutgers Van Der Loeff, M., Matthew, A., Willard, S., 2018. Radium Isotopes Across the Arctic Ocean Show Time Scales of Water Mass Ventilation and Increasing Shelf Inputs. J. Geophys. Res. Ocean. 123.

Rutgers van der Loeff, M.M., Berger, G.W., 1993. Scavenging of 230Th and 231Pa near the antarctic polar front in the South Atlantic. Deep. Res. Part I 40, 339-357. https://doi.org/10.1016/0967-0637(93)90007-P

Rutgers Van Der Loeff, M.M., Boudreu, B.P., 1997. the effect of resuspension on chemical exchanges at the sediment-water interface in the deep sea: a modelling and natural radiotracer approach. J. Mar. Syst. 11, 305-342.

Schlosser, P., Kromer, B., Ekwurzel, B., Bönisch, G., McNichol, A., Schneider, R., von Reden, K., Östlund, H.G., Swift, J.H., 1997. The first trans-Arctic 14C section: comparison of the mean ages of the deep waters in the Eurasian and Canadian basins of the Arctic Ocean. Nucl. Instruments Methods Phys. Res. Sect. B Beam Interact. with Mater. Atoms 123, 431-437. https://doi.org/10.1016/S0168-583X(96)00677-5

Scholten, J.C., Fietzke, J., Mangini, A., Garbe-Schönberg, C.D., Eisenhauer, A., Schneider, R., Stoffers, P., 2008. Advection and scavenging: Effects on 230Th and 231Pa distribution off Southwest Africa. Earth Planet. Sci. Lett. 271, 159-169. https://doi.org/10.1016/j.epsl.2008.03.060

Scholten, J.C., Rutgers van der Loeff, M.M., Michel, A., 1995. Distribution of 230Th and $231 \mathrm{~Pa}$ in the water column in relation to the ventilation of the deep Arctic basins. Deep. Res. Part II 42, 1519-1531. https://doi.org/10.1016/0967-0645(95)00052-6

Smith, J.N., Moran, S.B., Macdonald, R.W., 2003. Shelf-basin interactions in the Arctic Ocean based on $210 \mathrm{~Pb}$ and $\mathrm{Ra}$ isotope tracer distributions. Deep. Res. Part I Oceanogr. Res. Pap. 50, 397-416. https://doi.org/10.1016/S0967-0637(02)00166-8

Tanhua, T., Jones, E.P., Jeansson, E., Jutterstro, S., Jr, W.M.S., Wallace, D.W.R., Anderson, L.G., 2009. Ventilation of the Arctic Ocean: Mean ages and inventories of anthropogenic CO2 and CFC-11. J. Geophys. Res. 114, 1-11. https://doi.org/10.1029/2008JC004868

Valk, O., Rutgers van der Loeff, M.M., Geibert, W., Gdaniec, S., Rijkenberg, M.J.A., Moran, S.B., Lepore, K., Edwards, R.L., Lu, Y., Puigcorbé, V., 2018. Importance of hydrothermal vents in scavenging removal of ${ }^{230}$ Th in the Nansen Basin. Geophys. Res. Lett. 1-10. https://doi.org/10.1029/2018GL079829

Venchiarutti, C., Roy-Barman, M., Freydier, R., Van Beek, P., Souhaut, M., Jeandel, C., 2011a. Influence of intense scavenging on $\mathrm{Pa}$-Th fractionation in the wake of Kerguelen Island (Southern Ocean). Biogeosciences 8, 3187-3201. https://doi.org/10.5194/bg-83187-2011

Venchiarutti, C., van der Loeff, M.R., Stimac, I., 2011b. Scavenging of 231Pa and thorium isotopes based on dissolved and size-fractionated particulate distributions at Drake Passage (ANTXXIV-3). Deep. Res. Part II Top. Stud. Oceanogr. 58, 2767-2784. https://doi.org/10.1016/j.dsr2.2010.10.040 
Wassmann, P., Vernet, M., Mitchell, B., Rey, F., 1990. Mass sedimentation of Phaeocystis pouchetii in the Barents Sea. Mar. Ecol. Prog. Ser. 66, 183-195. https://doi.org/10.3354/meps066183

\section{Figures and tables}

Figure 1: Samples for the analysis of dissolved and particulate ${ }^{231} \mathrm{~Pa},{ }^{230} \mathrm{Th}$ and ${ }^{232} \mathrm{Th}$ were collected at 9 stations along the GEOTRACES GN04 section in the Arctic Ocean. Crossed symbols denote sampling for particulate and dissolved samples and non-crossed points are stations which were sampled for the analysis of dissolved concentrations.

Figure 2: Dissolved concentrations of ${ }^{231} \mathrm{~Pa}_{\mathrm{xs}},{ }^{230} \mathrm{Th}_{\mathrm{xs}}$ and ${ }^{232} \mathrm{Th}$ for shelf stations (upper panel) and deep stations (lower panel). Diamonds: Nansen Basin, squares: Amundsen basin, triangles: Makarov Basin and circles: shelf stations.

Figure 3: Particulate concentrations of ${ }^{231} \mathrm{~Pa}_{\mathrm{xs}},{ }^{230} \mathrm{Th}_{\mathrm{xs}}$ and ${ }^{232} \mathrm{Th}$ for shelf stations (upper panel) and deep stations (lower panel). Diamonds: Nansen Basin, triangles: Makarov Basin and circles: shelf stations

Figure 4: Pa-Th Fractionation factors. Diamonds: Nansen Basin, triangles: Makarov Basin and circles: shelf stations.

Figure 5: Depth profiles of (a) the particulate/total ratios of ${ }^{231} \mathrm{~Pa}_{\mathrm{xs}}$ and (b) particulate/total ratios for ${ }^{230} \mathrm{Th}_{\mathrm{xs}}$. Diamonds: Nansen Basin, triangles: Makarov Basin and circles: shelf stations.

Figure 6: Schematic representation of the boundary scavenging profile model: the margin and open ocean boxes exchange a total flux of water $(F)$. Vertical mixing is neglected. Particles are introduced in the surface waters of the ocean margin and interior and at all depths in the margin box (bent arrows). Particles are then transported by currents between the margin and ocean interior.

Figure 7: Boundary scavenging model outputs. Modelled profiles of (a and d): particle abundance and the ${ }^{230} \mathrm{Th}$ particulate fraction, ( $\mathrm{b}$ and e): dissolved and particulate ${ }^{230} \mathrm{Th}_{\mathrm{xs}}$ and $\mathrm{c}$ and $\mathrm{f}$ ): dissolved and particulate ${ }^{231} \mathrm{~Pa}_{\mathrm{xs}}$ in comparison with measured data obtained at station 32 (margin) and 50 (interior). Pink open diamonds (st 32) and orange diamonds (st 50) represent measured data while the pink lines represent the margin model and orange lines represent the interior ocean model.

Figure 8: Dissolved ${ }^{231} \mathrm{~Pa}_{\mathrm{xs}}$ versus DSi measured during PS94 (Van Ooijen et al., 2016). Diamonds: Nansen Basin, squares: Amundsen basin, triangles: Makarov Basin and circles: shelf stations.

Table 1: Parameters of the Boundary scavenging profile model 


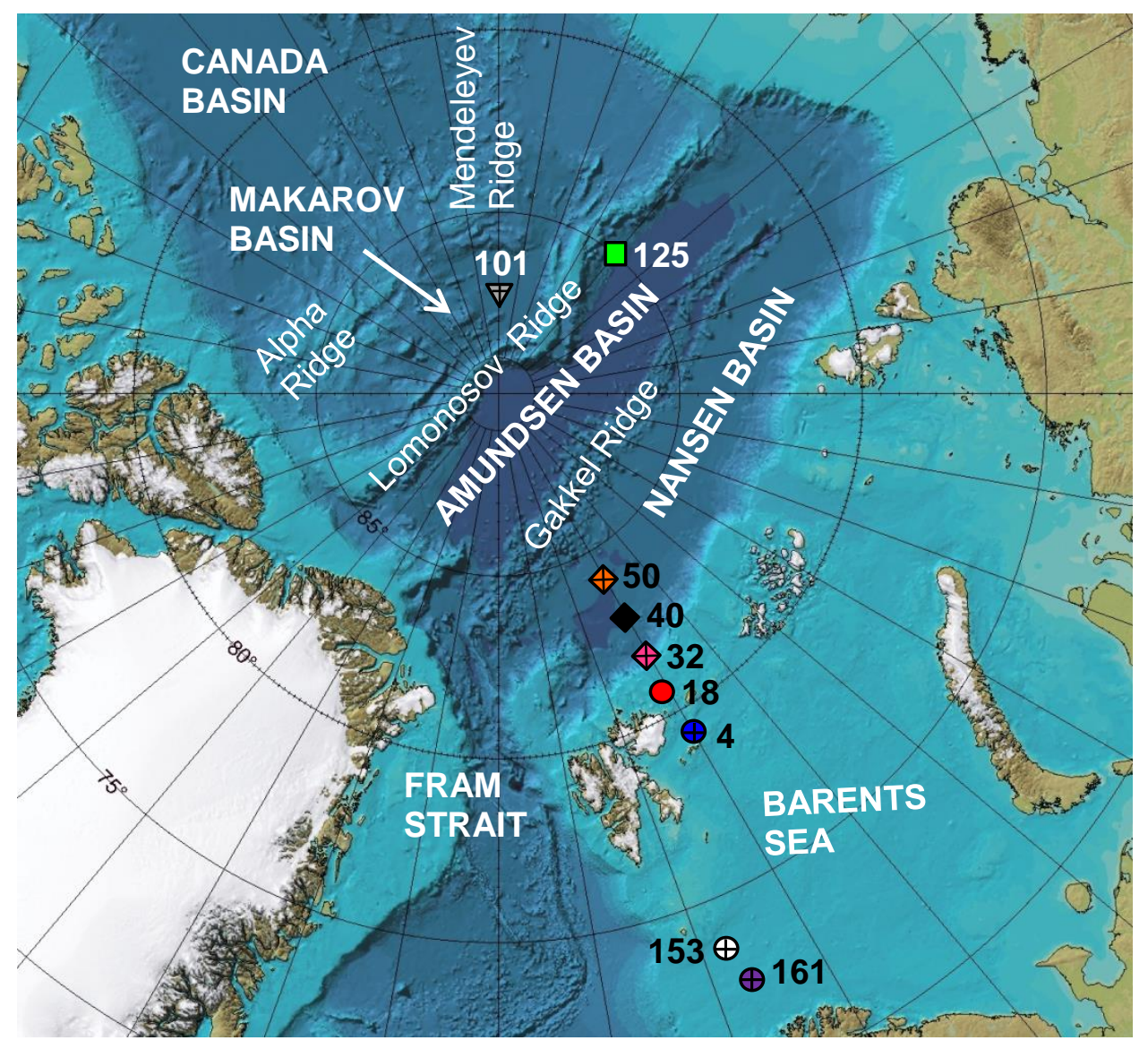


Dissolved ${ }^{231} \mathrm{~Pa}_{\mathrm{xs}}(\mathrm{fg} / \mathrm{kg}) \quad$ Dissolved ${ }^{230} \mathrm{Th}_{\mathrm{xs}}(\mathrm{fg} / \mathrm{kg}) \quad$ Dissolved ${ }^{232} \mathrm{Th}(\mathrm{pg} / \mathrm{kg})$

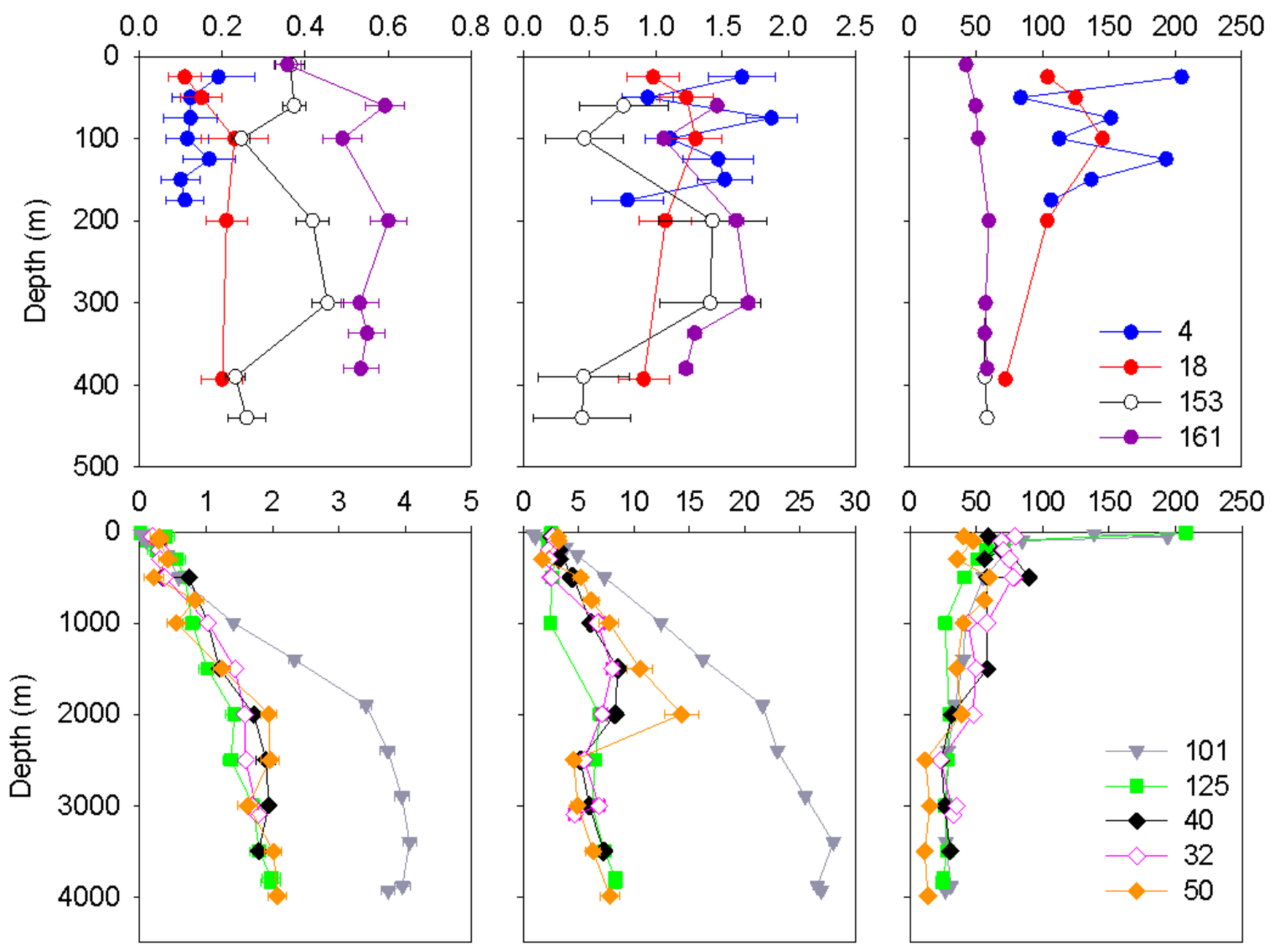


$\mathrm{F}_{\mathrm{Th} / \mathrm{Pa}}$

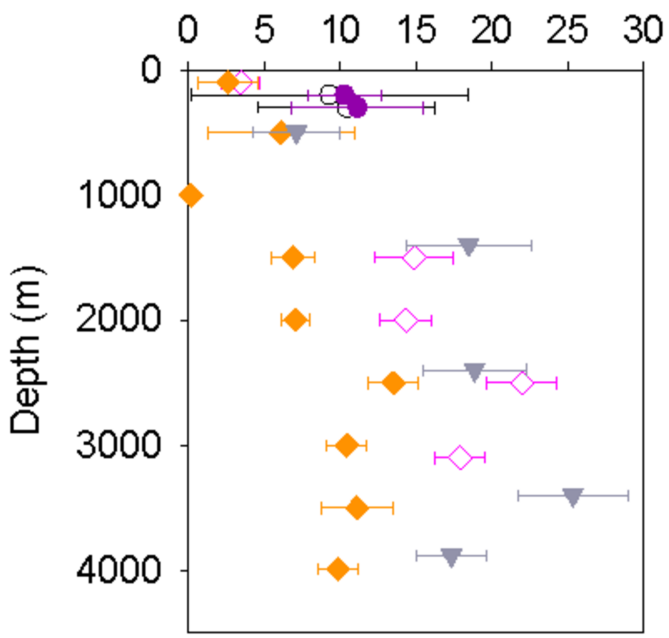

$\diamond \quad 32$ 50

- 101

- 153

- 161 
Particulate fraction of ${ }^{231} \mathrm{~Pa}_{\mathrm{xs}} \quad$ Particulate fraction of ${ }^{230} \mathrm{Th}_{\mathrm{xs}}$

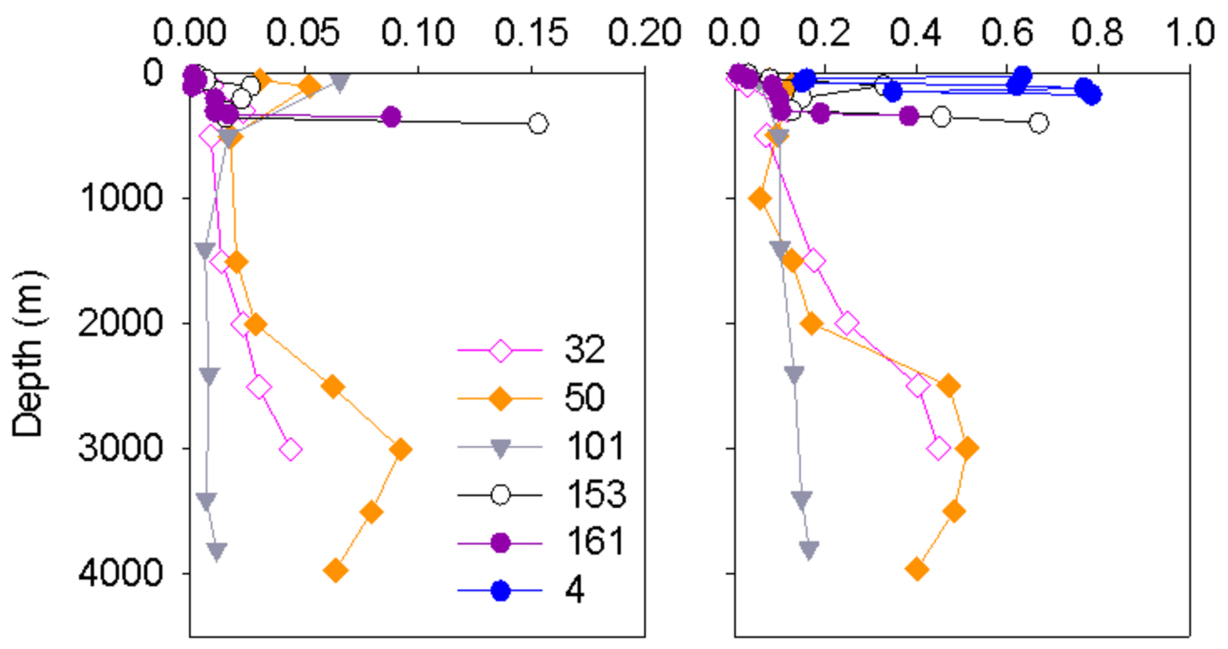




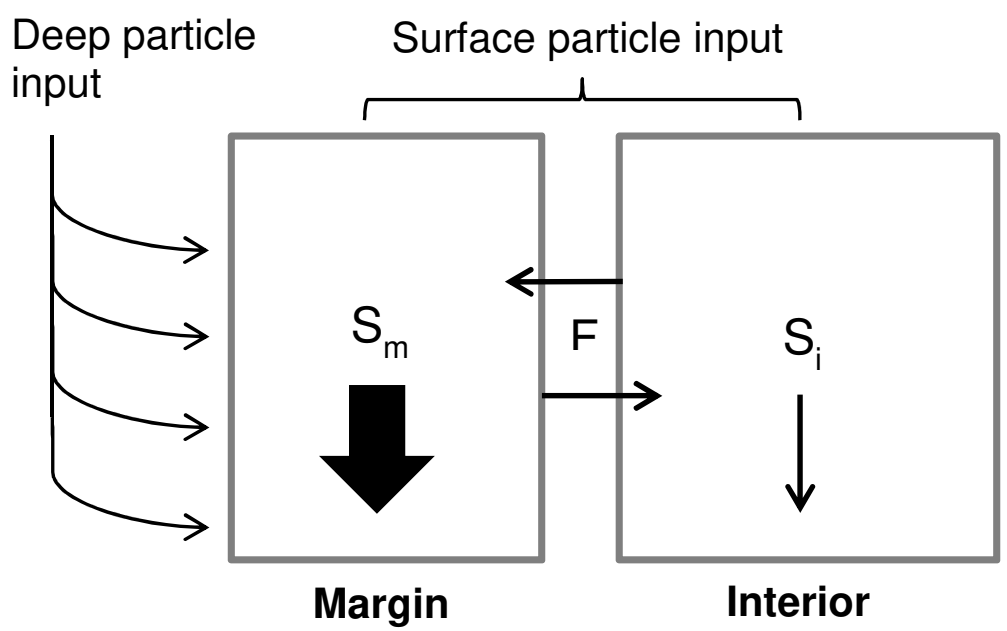



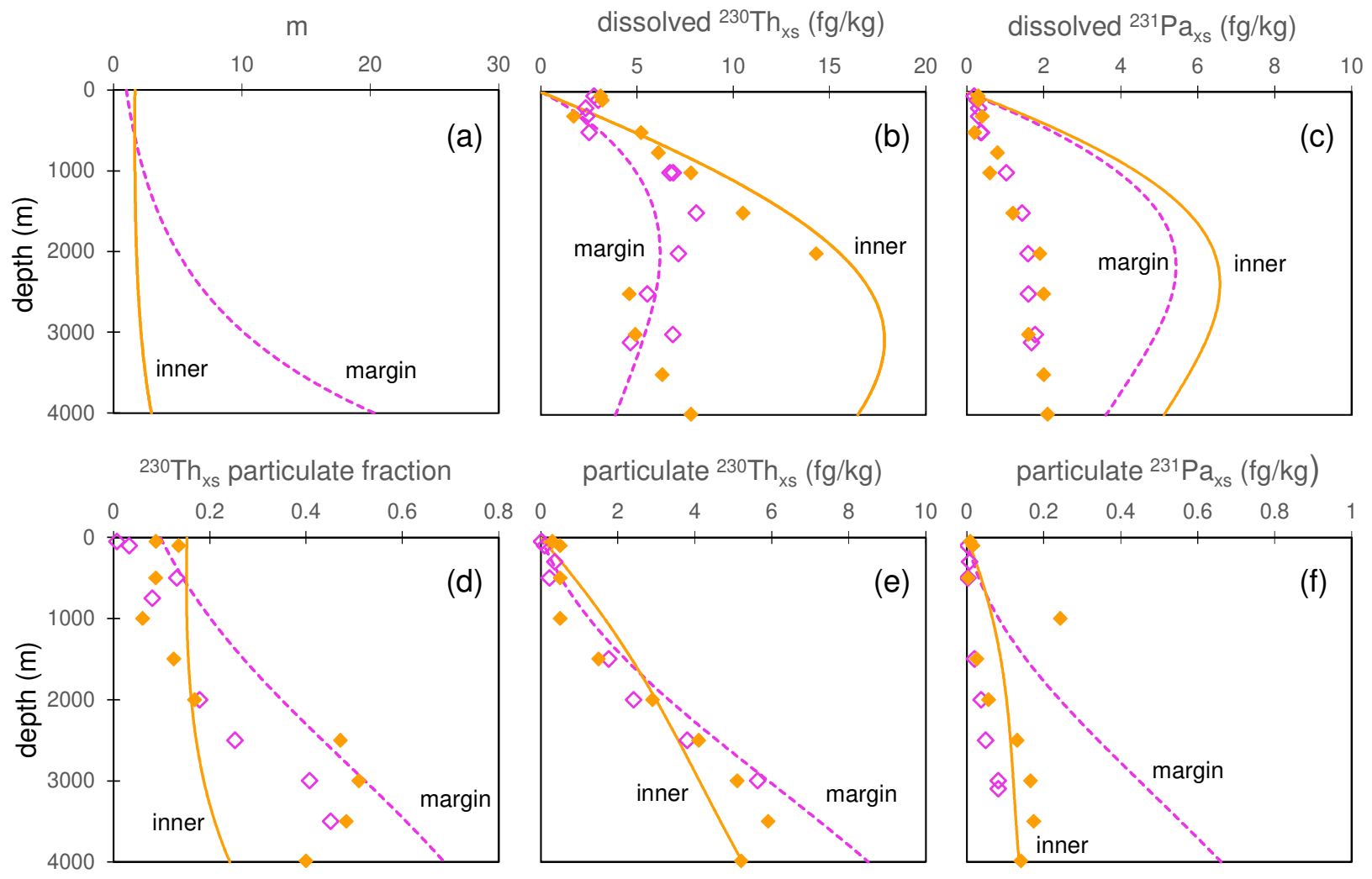
Table 1. Parameters of the Boundary scavenging profile model

\begin{tabular}{lcc}
\hline Parameter & Ocean interior & Ocean margin \\
\hline $\mathrm{V}\left(\mathrm{m}^{3}\right)$ & $6.5 \times 10^{15}$ & $1.5 \times 10^{15}$ \\
$\mathrm{~F}\left(\mathrm{~m}^{3} / \mathrm{y}\right)$ & $1.3 \times 10^{14}$ & $1.3 \times 10^{14}$ \\
$\mathrm{~T}(\mathrm{y})$ & 50 & 10 \\
$\mathrm{k}$ & 0.02 & 0.1 \\
$\mathrm{~S}(\mathrm{~m} / \mathrm{y})$ & 300 & 600 \\
$\mathrm{~K}^{230} \mathrm{Th}$ & 0.11 & 0.11 \\
$\mathrm{~K}^{231} \mathrm{~Pa}$ & 0.0075 & 0.0075 \\
$\mathrm{P}^{230} \mathrm{Th}\left(\mathrm{fg} / \mathrm{m}^{3} / \mathrm{y}\right)$ & 0.056 & 0.056 \\
$\mathrm{P}^{231} \mathrm{~Pa}\left(\mathrm{fg} / \mathrm{m}^{3} / \mathrm{y}\right)$ & 0.025 & 0.025 \\
$\mu\left(\mathrm{y}^{-1}\right)$ & & 0.5 \\
$\mathrm{~m}(0)$ & 1.5 & 1 \\
\hline
\end{tabular}

